\title{
3213 SAYILI MADEN KANUNU UYARINCA MADEN HUKUKUNDA KAMULAŞTIRMA USULÜ \\ Muradiye ÇEVİKÇELİK*
}

$\ddot{O} Z$

Madenler, fiziki koşullar sebebiyle bulundukları arazide üretilmek zorundadır. Işletme aşamasında, ruhsat alanında gerekli bina ve tesisler inşa edilerek işletme faaliyetlerine başlanacaktır. Ancak ruhsat alanının özel hukuk kişisinin mülkiyetinde olması halinde, ruhsat sahibine söz konusu taşınmaz üzerinde tasarrufta bulunma imkânının să̆lanması gerekmektedir. Bu kapsamda Maden Kanunu'nda ruhsat sahibi lehine özel hukuk kişisine ait taşınmaz üzerinde irtifak ve/veya intifa hakkı tesis edilebileceği veya taşınmazın kamulaştırılabileceği ifade edilmiştir. Ruhsat alanının kamulaştırllması, idarenin taşınmaz malı cebren elde etmesi dolayısıla mülkiyet hakkının özüne dokunan bir uygulamadır. Dolayısıyla, kamulaştırma işleminin maden hukukuna özgü yönlerinin ortaya konulması bir gerekliliktir. Bu makale kapsamında öncelikle kamulaştırma kurumuna ilişkin temel noktalara değinilecektir. Sonrasında ise kamulaştırmaya ilişkin Maden Kanunu'nun 46. maddesinde yer alan ayrısı düzenlemeler ele alınacaktır.

Anahtar Kelimeler: Maden Hukuku, Kamulaştırma, Maden İşletme Ruhsatı, Kamu Yararl, Geri Alma Hakkl.

\section{THE EXPROPRIATION PROCEDURE IN MINING LAW ACCORDING TO THE MINING LAW NUMBER 3213}

\section{ABSTRACT}

Minerals, because of physical conditions, must be produced in the land where they are located. In the operation phase, the necessary buildings and facilities will be built in the license area and operational activities will begin. However, if the license area is the property of the private person, the licensee must be given the opportunity to work on the real estate. In this context, it is stated in the Mining Law that right of easement and/or right of usufruct can be established on the real estate of the private person in favor of the licensee or that the real estate can be expropriated. The expropriation of the license area is an application that touches the essence of the right of property. Because the administration obtains real estate by force. Therefore, it is a necessity to reveal the expropriation process in the Mining Law. In this article,

\footnotetext{
Ar. Gör., Necmettin Erbakan Üniversitesi Hukuk Fakültesi İdare Hukuku Anabilim Dalı, e-posta:mcevikcelik@erbakan.edu.tr, 
firstly, the outlines of the expropriation will be addressed. Subsequently, the especial regulations in Article 46 of the Mining Law on expropriation will be discussed.

Keywords: Mining Law, Expropriation, Mining License, Public Interest, Right to Restitution.

\section{GíRiş}

Maden kavramı, uygulamada ve doktrinde üzerinde uzlaşılan bir tanım mevcut olmamakla birlikte, genel olarak, iç ve/veya diş doğal etkenlerle yerkabuğunda oluşan ve ekonomik değere sahip olan mineraller şeklinde ifade edilmektedir ${ }^{1}$.

Hukuki, ekonomik ve siyasi alanda oldukça önem taşıyan madenler için hukukumuzdaki temel düzenleme Anayasa'nın "Tabiî servetlerin ve kaynakların aranması ve işletilmesi” başl1klı 168. maddesidir ${ }^{2}$. Her ne kadar 168. maddede tabiî servet ve kaynaklar ifadesi tanımlanmamış ve söz konusu kavramın kapsamına giren maddeler sayılmamış olsa da, maden kavramının tabiî servet ve kaynaklardan biri ${ }^{3}$ ve belki de en önemlisi olduğu aşikârdır. Zira madenler insanlık tarihine yön veren pek çok gelişmenin itici gücü olmasının yanı sıra ${ }^{4}$, milyonlarca insanın ölümüne yol açan ve dünyayı kana bulayan savaşların da en önemli nedenlerinden birisidir.

1 Sanayi ve Teknoloji Bakanlığı'nın ilgili kuruluşu olan Eti Maden İşletmeleri Genel Müdürlügü̈'nün sitesinde yer alan Maden Terimleri Sözlüğü'nde maden kavramı şöyle tanımlanmıştır: "1) Yerkabuğunun kimi bölgelerinde çeşitti iç ve dış doğal etkenler nedeni ile oluşan, ekonomik yönden değer taşıyan mineral bileşimi. 2) Kendine özgü bir partltısı olan, genellikle elektriği ve isty ileten, oksijenle birleşerek bazal etki veren (basit cisim) element. 3) Maden ocağgl, -işletmesi" Eti Maden İşletmeleri Genel Müdürlüğü: Maden Terimleri Sözlüğü, (http://www.etimaden.gov.tr/maden-terimleri-sozlugu/m-harfi-ilebaslayanlar\#, Erişim Tarihi: 25.08.2019).

2 "Madde 168 - Tabii servetler ve kaynaklar Devletin hüküm ve tasarrufu altındadır. Bunların aranması ve işletilmesi hakkı Devlete aittir. Devlet bu hakkını belli bir süre için, gerçek ve tüzelkişilere devredebilir. Hangi tabii servet ve kaynağın arama ve işletmesinin, Devletin gerçek ve tüzelkişilerle ortak olarak veya doğrudan gerçek ve tüzelkişiler eliyle yapılması, kanunun açık iznine bağlıdır. Bu durumda gerçek ve tüzelkişilerin uyması gereken şartlar ve Devletçe yapılacak gözetim, denetim usul ve esaslarl ve müeyyideler kanunda gösterilir."

3 GÖĞER, s. 38-40; GÜNAY, s. 19; KIRBAŞ, s. 25.

4 Madencilik faaliyetlerinin önemine ilişkin değerlendirmeler için bkz. ÇİTİL, s. 35-38.

330 Ankara Hacı Bayram Veli Üniversitesi Hukuk Fakültesi Dergisi C. XXIV, Y. 2020, Sa. 1 
Taşıdığı ekonomik ve stratejik önem karşısında madenler, hukukumuzda pek çok yasal düzenlemede ele alınmaktadır. $\mathrm{Bu}$ çalışmanın konusunu oluşturan temel düzenleme ise 3213 sayılı Maden Kanunu (MK) ${ }^{5}$ 'dur.

Öncelikle ifade edilmelidir ki, yukarıda verilen tanım maden kavramının bilimsel bir ifadesidir. Her ülke, kendi politikaları doğrultusunda mevzuatında "maden" olarak adlandırdığı kavramın kapsamını belirlemekte özgürdür. $\mathrm{Bu}$ durum bilimsel açıdan maden olarak değerlendirilen bir maddenin hukuki açıdan maden sayılmaması ve maden kanunu kapsamında değerlendirilmemesi sonucunu doğurmaktadır. Aynı doğrultuda bilimsel açıdan maden olarak değerlendirilmeyen bir maddenin hukuki açıdan maden sayılıp maden kanunu kapsamına dâhil edilmesi mümkündür'. Mevzuatımızda da "maden" kavramı, Maden Kanunu'nun 2. maddesi ile tanımlanmış ve madenler beş gruba ayrılarak ele alınmıştır ${ }^{7}$.

$5 \quad$ 15.06.1985 tarih ve 18785 say1l Resmi Gazete.

6 GÜLAN, (2008), s. 129.

7 "Madenler:

Madde 2 - (Değişik: 26/5/2004 - 5177/1 md.) Yer kabuğunda ve su kaynaklarında tabii olarak bulunan, ekonomik ve ticarî değeri olan petrol, doğal gaz, jeotermal ve su kaynaklarl dişında kalan her türlü madde bu Kanuna göre madendir.

Madenler aşă̆ıda sıralanan gruplara göre ruhsatlandırılır:

I. Grup madenler

a) Inşaat ile yol yapımında kullanılan ve tabiatta doğal olarak bulunan kum ve çakıl.

b) Tuğla-kiremit kili, Çimento kili, Marn, Puzolanik kayaç (Tras) ile çimento ve seramik sanayilerinde kullanılan ve diğer gruplarda yer almayan kayaçlar.

II. (Değişik: 10/6/2010-5995/1 md.) Grup madenler

a) (Değişik: 4/2/2015-6592/1 md.) Kalsit, Dolomit, Kalker, Granit, Andezit, Bazalt gibi kayaçlardan agrega, hazır beton ve asfalt yapılarak kullanılan kayaçlar.

b) Mermer, Traverten, Granit, Andezit, Bazalt gibi blok olarak üretilen taşlar ile dekoratif amaçla kullanılan doğal taşlar.

c) (Ek: 4/2/2015-6592/1 md.) Kalsit, Dolomit, Kalker, Granit, Andezit, Bazalt gibi kayaçlardan entegre çimento, kireç ve kalsit ögütme tesisinde kullanılan kayaçlar.

III. Grup madenler

Deniz, göl, kaynak suyundan elde edilecek eriyik halde bulunan tuzlar, karbondioksit (CO2) gazı (jeotermal, doğal gaz ve petrollü alanlar hariç) Hidrojen Sülfür (7/3/1954 tarihli ve 6326 sayll Petrol Kanunu hükümleri mahfuz kalmak kaydıyla).

IV. Grup madenler

a) Kaolen, Dikit, Nakrit, Halloysit, Endellit, Anaksit, Bentonit, Montmorillonit, Baydilit, Nontronit, Saponit, Hektorit, Illit, Vermikülit, Allofan, İmalogit, Klorit, Sepiyolit, Paligorskit (Atapuljit), Loglinit ve bunların karışımı killer, Refrakter killer, Jips, Anhidrit, Alünit (Şap), Halit, Sodyum, Potasyum, Lityum, Kalsiyum, Magnezyum, Klor, Nitrat, Iyot, Flor, Brom ve 
Anayasa'nın 168. maddesi ve Maden Kanunu'nun 4. maddesi uyarınca madenler devletin hüküm ve tasarrufu altındadır ${ }^{8}$. Bu durum Anayasa'nın 168. maddesinde "Tabii servetler ve kaynaklar Devletin hüküm ve tasarrufu altındadır. Bunların aranması ve işletilmesi hakkı Devlete aittir”, Maden Kanunu'nun 4. maddesinde ise "Madenler Devletin hüküm ve tasarrufu altında olup, içinde bulundukları arzın mülkiyetine tabi değildir” şeklinde ifade edilmiștir. Söz konusu hükümler hukukumuzda madenler açısından

diğer tuzlar, Bor tuzlarl (Kolemanit, Uleksit, Borasit, Tinkal, Pandermit veya bünyesinde en az \%10 B2O3 içeren diğer Bor mineralleri), Stronsiyum tuzları (Selestin, Stronsiyanit), Barit, Vollastonit, Talk, Steattit, Pirofillit, Diatomit, Olivin, Dunit, Sillimanit, Andaluzit, Dumortiorit, Disten (Kyanit), Fosfat, Apatit, Asbest (Amyant), Manyezit, Huntit, Tabî Soda mineralleri (Trona, Nakolit, Davsonit), Zeolit, Pomza, Pekştayn, Perlit, Obsidyen, Grafit, Kükürt, Flüorit, Kriyolit, Zımpara Taşl, Korundum, Diyasporit, Kuvars, Kuvarsit ve bileşiminde en az \%80 SiO2 ihtiva eden Kuvars kumu, Feldispat (Feldispat ve Feldispatoid grubu mineraller), Mika (Biyotit, Muskovit, Serisit, Lepidolit, Flogopit), Nefelinli Siyenit, Kalsedon (Sileks, Çört).

b) Turba, Linyit, Taşkömürü, (...) Antrasit, Asfaltit, Bitümlü Şist, Bitümlü Şeyl, (...)Kokolit ve Sapropel (Petrol Kanunu hükümleri mahfuz kalmak kaydlyla).

c) Altın, Gümüş, Platin, Bakır, Kurşun, Çinko, Demir, Pirit, Manganez, Krom, Civa, Antimuan, Kalay, Vanadyum, Arsenik, Molibden, Tungsten (Volframit, Şelit), Kobalt, Nikel, Kadmiyum, Bizmut, Titan (Ilmenit, Rutil), Alüminyum (Boksit, Gipsit, Böhmit), Nadir toprak elementleri (Seryum Grubu, Yitriyum Grubu) ve Nadir toprak mineralleri (Bastnazit, Monazit, Ksenotim, Serit, Oyksenit, Samarskit, Fergusonit), Sezyum, Rubidyum, Berilyum, Indiyum, Galyum, Talyum, Zirkonyum, Hafniyum, Germanyum, Niobyum, Tantalyum, Selenyum, Telluryum, Renyum.

c) (Ek: 4/2/2015-6592/1 md.) Uranyum, Toryum, Radyum gibi elementleri içeren radyoaktif mineraller ve diğer radyoaktif maddeler.

V. Grup madenler Elmas, Safir, Yakut, Beril, Zümrüt, Morganit, Akuvamarin, Heliodor, Aleksandirit, Agat, Oniks, Sardoniks, Jasp, Karnolin, Heliotrop, Kantaşı, Krizopras, Opal (Irize Opal, Kırmızı Opal, Siyah Opal, Ăgaç Opal), Kuvars kristalleri (Ametist, Sitrin, Neceftaşı (Dăg kristali), Dumanlı Kuvars, Kedigözü, Avanturin, Venüstaşı, Gül Kuvars), Turmalin (Rubellit, Vardelit, Indigolit), Topaz, Aytaşı, Turkuaz (Firuze), Spodümen, Kehribar, Lazurit (Lapislazuli), Oltutaşl, Diopsit, Amozonit, Lületaşı, Labrodorit, Epidot (Zeosit, Tanzonit), Spinel, Jadeit, Yeșim veya Jad, Rodonit, Rodokrozit, Granat Minarelleri (Spesartin, Grosüllar Hessanit, Dermontoit, Uvarovit, Pirop, Almandin), Diaspor Kristalleri, Kemererit.

VI. (Ek: 10/6/2010-5995/1 md.; Mülga: 4/2/2015-6592/1 md.)

Bu gruplarda yer alan madenlerin özellikleri ile bu maddede yer almayan bir madenin grubunun tespitine ait esas ve usuller Bakanlıkça çıkarllacak yönetmelikle düzenlenir.

Bu Kanuna göre verilen ruhsatlar başka amaçla kullanılmaz."

8 Doktrinde ve yarg1 kararlarında "devletin hüküm ve tasarrufu altında olma" ifadesinin anlamı ve içeriği üzerinde görüş birliği bulunmamaktadır. En genel ifadeyle devletin hüküm ve tasarrufu altındaki yerler, "devletin, devlet olma vasfi dolayısiyla egemenliği altında bulundurduğu yerlerdir”. ŞİMŞEK, s. 96; Bu husustaki tartışmalar için bkz. SÖYLER, s. $62-66$ 
kamu mülkiyeti sisteminin ${ }^{9}$ kabul edildiğinin bir göstergesidir ${ }^{10}$.

Madenler açısından kamu mülkiyeti sisteminin kabul edilmesi, madenin bulunduğu arazi sahibinin mülkiyet hakkının ${ }^{11}$ sinırlandırılması sonucunu doğurmaktadır. Zira madenlerin mülkiyetinin arzın mülkiyetinden ayrı tutularak devletin hüküm ve tasarrufu altına sayılması, taşınmaz malikinin mülkiyet hakkının dikey kapsamına ${ }^{12}$ müdahale niteliği taşımaktadır. Mülkiyet hakkının kamu yararı amacıyla ve kanunla sınırlandırılabileceğini ifade eden Anayasa'nın 35. maddesinin 2. fikrası karşısında, mülkiyet hakkının dikey kapsamına Anayasa'nın 168 ve Maden Kanunu'nun 4. maddesi ile getirilen sinırlandırmalar hukuka uygundur. Zira madencilik faaliyetlerinin yürütülmesinde kamunun yararı olduğu aşikârdır ${ }^{13}$.

Ülkemizde Maden Kanunu uyarınca madenlerin işletilmesinde ruhsat usul $\ddot{u}^{14}$ uygulanmaktadır. Madencilik faaliyetinde bulunmak isteyen kişiler, öncelikle idareye başvurarak maden arama ruhsatı almak zorundadırlar ${ }^{15}$. Arama döneminde ruhsata dayanılarak yürütülen arama faaliyetleri neticesinde, keşfedilen maden yatağındaki madeni çıkarmak ve bu amaçla çeşitli tesisler

9 GÜLAN'a göre, "hüküm ve tasarruf" ifadesi yeterince açık değildir. Ancak bu ifade ile özel mülkiyetin kastedilmediği aşikârdır. GÜLAN, (1999), s. 84.

10 AZRAK, s. 3-4; ERDOĞAN, s. 48; FINDIKLIGİL, s. 78-80; GÖĞER, s. 136; KALABALIK, s. 309; ÖĞÜTÇÜ, s. 206; TELLİ, s. 48-49; TÜRK, s. 83-85. YILDIZ, s. 1976.

11 "...Mülkiyet hakkl yatay ve dikey olarak taşınmazda kanunla yapılan sinırlamalar dişında sahibine tam bir kullanma ve buna elatma halinde ise eksiksiz koruma sağlar...", Yargitay 14. Hukuk Dairesi, T. 05.04.2007, E. 2007/1236, K. 2007/3613, Kazanc1 İçtihat Bilgi Bankasi.

12 Mülkiyet hakkının dikey kapsamı 4721 sayılı Medeni Kanun'un 718. maddesinde şöyle düzenlenmiştir: "Madde 718- Arazi üzerindeki mülkiyet, kullanılmasında yarar olduğu ölçüde, üstündeki hava ve altındaki arz katmanlarını kapsar.

Bu mülkiyetin kapsamına, yasal sınırlamalar saklı kalmak üzere yapılar, bitkiler ve kaynaklar da girer."

13 GÜLAN, (2008), s. 238; ÖZTOPRAK, s. 53-54; TELLİ, s. 77; ÇİTIL; s. 29; GÜNAY’a göre ise "Her türlü Madencilik faaliyeti kamu yararına değildir, somut olayın durumuna göre kamu yararı olup olmadığına karar verilmelidir" GÜNAY, s. 83.

14 Ruhsat usulü, kanunda açıkça öngörülmek kaydıyla, bir kamu hizmetinin idarenin tek taraflı işlemiyle ve işlevsel denetimi altında özel hukuk kişilerine gördürülmesidir. GÜLAN, (1987), s. 69, GÜNDAY, s. 362; Ruhsat kurumunun, kamu hizmetinin özel kesime gördürülmesi yöntemi olarak kabul edilemeyeceğine ilişkin görüş için bkz. KARAHANOĞULLARI, s. 324-326.

15 Maden Kanunu'nun 16. maddesinin ilk fikrası uyarınca; II. grup (b) bendi, III. grup, IV. grup madenler ile V. grup madenler arama ruhsatı ile aranacaklardır. I. grup, II. grup (a) ve (c) bendi madenler içinse doğrudan işletme ruhsatı verilecektir. 
kurmak isteyen kişilerin idareye başvurarak maden işletme ruhsatı almaları gerekmektedir $^{16}$ (MK m. 24).

Maden arama veya işletme ruhsatı alınması, ruhsat sahibine ruhsata konu alan üzerinde doğrudan madencilik faaliyetlerinde bulunmak konusunda bir yetki vermemektedir. Zira Anayasa'nın 35. maddesinin 2. fikrası uyarınca, mülkiyet hakkı yalnızca kamu yararını gerçekleştirmek amacıyla kanunla sınırlandırılabilir. Dolayısıyla tipik bir idari işlem olan ruhsat işlemi ${ }^{17}$ ile kişilerin mülkiyet haklarının sınırlandırılması mümkün değildir. Bu kapsamda ruhsat sahibine ruhsata konu alanda madencilik faaliyetlerinde bulunabilmesi için Maden Kanunu'nda iki farklı yol öngörülmüştür: İrtifak veya intifa hakkının tanınması ve kamulaştırma. Bu çalışmanın konusunu maden hukukuna özgü yönleriyle Maden Kanunu'nun 46. maddesinde düzenlenen kamulaştırma işlemi oluşturmaktadır. Maden hukukunda kamulaştırma işleminin kendine has yönlerinin daha iyi anlaşılması amacıyla, öncelikle 2942 sayılı Kamulaştırma Kanunu (KK) ${ }^{18}$ 'nda öngörülen usul ve esaslar kısaca ele alınacaktır. Sonrasında ise Maden Kanunu'nun 46. maddesi çerçevesinde, kamulaştırma işleminin maden hukukunda farklılık arz eden yönleri üzerinde durulacaktır.

\section{KAMULASTTIRMA ${ }^{19}$}

Kamulaştırma, devlet veya diğer kamu tüzel kişilerinin, kamu yararını gerçekleştirmek için ihtiyaç duydukları özel kişilere ait taşınmaz malların tamamının veya bir kısmının, gerçek değerini peşin ödemek kaydıyla ve maliklerin rızalarına bakmaksızın, kanunda gösterilen usul ve esaslar

16 ÇEVIKÇELİK, s. 109-110; GÖĞER, s. 207; TELLİ, s.102.

17 Ruhsat işlemi, özel, somut ve kişisel bir düzenleme niteliği taşıdığı için birel işlem olarak adlandırılmaktadır. Birel işlem kapsamında yapılan şart işlem-sübjektif işlem ayrımında ise ruhsat işlemi şart işlem olarak değerlendirilmektedir. Zira şart işlem ile bir kişi veya nesne, önceden genel, soyut ve kişilik dışı kurallarla belirlenmiş bir hukuki statüye sokulmakta veya o hukuki statüden çıkarılmaktadır. AKYILMAZ/ SEZGINER/ KAYA, s. 330-331.

18 08.11.1983 tarih ve 18215 sayılı Resmi Gazete.

192942 sayılı Kamulaştırma Kanunu kapsamında yapılacak kamulaştırmalara ilişkin usul ve esasların ayrıntılı olarak ele alınması ayrı bir çalışmanın konusunu oluşturacak niteliktedir. Dolayısıyla maden hukukuna özgü yönlerinin karşılaştırma yapılarak daha iyi anlaşılabilmesi amacıyla bu başlık altında kamulaştırma süreci genel hatlarıyla ele alınacaktır. 
doğrultusunda kamu gücü ${ }^{20}$ kullanarak elde etmeleridir ${ }^{21}$. Anayasa'nın 46. maddesinde düzenlenen kamulaştırma, 35. maddede yer alan mülkiyet hakkına önemli bir müdahaledir ${ }^{22}$. Zira 35. madde ile kamu yararı gerektirdiğinde mülkiyet hakkının kanunla sınırlandırılabileceği kabul edilmiştir. Oysa kamulaştırma ile özel hukuk kişisinin mülkiyet hakkı sınırlandırılmamakta, tamamen ortadan kaldırılmaktadır ${ }^{23}$. Dolayısıyla kamulaştırma işlemi mülkiyet hakkının özüne dokunan bir uygulamadır ${ }^{24}$. Ancak Anayasa'nın 46. maddesinde ve Kamulaştırma Kanunu'nda belirtilen usul ve esaslara uygun hareket etmek kaydıyla, devlet veya kamu tüzel kişilerinin kamu yararının gerektirdiği hallerde özel hukuk kişilerinin taşınmaz mülkiyetine müdahalelerde bulunmaları hukuka aykırı bir nitelik taşımayacaktır ${ }^{25}$. Zira bu aşamada özel mülkiyetin cebren iktisabı, keyfi ve zorbalıkla yapılan bir iktisap değildir ${ }^{26}$.

Kamulaştırma ile söz konusu taşınmaz maliki, kamu yararını gerçekleştirmek uğruna mülkiyet hakkından fedakârlıkta bulunmak ve

20 Yargıtay 4. Hukuk Dairesi, eski tarihli bir kararında, kamulaştırmanın hukuki niteliğine ilişkin ortaya atılan teorilerden biri olan zorla satın alma teorisine kararını dayandırmış ve kamulaştırmanın satım sözleşmesinin özel bir türü olduğunu şöyle ifade etmiştir: “... Kamulaştırma alıcı kamu idaresinin yahut da 6309 sayıl Yasada gösterildiği gibi özel bir kişinin veya kuruluşun isteği üzerine idare tarafindan açıklanan tek taraflı bir işlemle bir taşınmazın mülkiyetinin Anayasa ve Yasada gösterilen yollarla idareye temlik edilmesidir. Bu işlem niteliğine göre alım satımın bir özel türüdür. Davacının malı böyle bir işlem gereğince idarece alınınca malının parasını derhal ve peşinen ödemesi gerekir. Bu işlem yapllmazsa alıcı idare kendiliğinden mütemerrit duruma düşer. Çünkü alım satım işlemlerinde her iki tarafin mal parasını koşul olarak aynı zamanda ödemesini Yasa buyurmuştur..." Yargıtay 4. Hukuk Dairesi, T. 06.04.1976, E. 1976/2856, K. 1976/3659, Ankara Barosu Dergisi, S. 4, 1976, s. 711; Zorla satın alma teorisine ilişkin ayrıntılı bilgi için bkz. DÜREN, s. 17; ÖZYÖRÜK, s. 99; ZEVKLİLER, s. 950; Bugün için kamulaştırma, kamu gücü kullanılarak tesis edilen idari bir tasarruf olup kamu hukuku işlemi niteliği taşımakta ve kamulaştırma sürecinde taşınmaz sahibinin rızasının olup olmaması önem arz etmemektedir. DÜREN, s.18.

21 AKYILMAZ/ SEZGINER/ KAYA, s. 591; ARTUKMAÇ, s. 11; ATAY, s. 810; GÖVEN, s. 248-249; GÖZLER, s. 646; ŞAHIN, s. 607; GÜNDAY, s. 250; KIRATLI, s. 55; KIRBAŞ, s. 61; KUTLU, s. 6-7; ÖZYÖRÜK, s. 230; ZEVKLİLER, s. 938.

22 Kamulaştırmanın mülkiyetten doğan ödev niteliğinde olup olmadığına ilişkin tartışmalar için bkz. DÜREN, s. 19-21; KUTLU, s. 10-12; ZEVKLİLER, s. 946-948.

23 DÜREN, s. 9.

24 AKYILMAZ/ SEZGINER/ KAYA, s. 591.

25 KUTLU, s. 52.

26 KIRATLI, s. 55.

Ankara Hacı Bayram Veli Üniversitesi Hukuk Fakültesi Dergisi C. XXIV, Y. 2020, Sa. 1335 
toplumdaki diğer bireylere kıyasla daha ağır bir külfete katlanmak zorundadır ${ }^{27}$. Kamulaştırma işlemi ile taşınmaz sahibi aleyhine bozulan dengenin tekrar sağlanması sosyal devlet ve hukuk devleti ilkelerinin bir gereğidir. Zira temel hak ve özgürlükleri tanıyı güvence altına alan hukuk devletinde, kamu yararı amacıyla hareket edilse dahi, toplumdaki bir bireyin diğer bireylere kıyasla daha ağır külfetlere karşılıksız olarak katlanması beklenemez ${ }^{28}$. Bu doğrultuda Anayasa'nın 46. maddesinde, kamulaştırılacak taşınmazın gerçek karșılığının peşin $^{29}$ ve nakden ${ }^{30}$ ödenmesi gerektiği hüküm altına alınmıştır. Söz konusu kamulaştırma bedelinin ödenmesiyle, taşınmazı kamulaştırılan özel hukuk kişisinin katlandığ fedakârlık denkleştirilmektedir ${ }^{31}$.

Anayasa'nın 46. maddesi ile düzenlenen bir diğer husus, özel mülkiyette bulunan taşınmazlar üzerinde idari irtifak ${ }^{32}$ kurulmasıdır. Kamulaştırma Kanunu'nun 4. maddesi ile amaç için yeterli olduğu durumlarda özel mülkiyette bulunan taşınmaz malın tamamen veya kısmen kamulaştırılması yerine, taşınmaz üzerinde idari irtifak tesis edilmesi yoluna başvurulabileceği ifade edilmiştir ${ }^{33}$. İrtifak hakkının tesisinde ise kamulaştırma usulü uygulanacaktır.

Kamulaştırma, idari işlem niteliği taşımakla birlikte, önce idari sonrasında ise adli olmak üzere iki farklı aşamadan geçilerek tesis

27 ULUSAN, s. 114-118; ZEVKLILLER, s. 946.

28 AKYILMAZ/ SEZGINER/ KAYA, s. 116.

29 Kamulaştırma bedelinin peşin ödenmesi kuraldır. Öte yandan Anayasa'nın 46. maddesi uyarınca, "tarım reformunun uygulanması, büyük enerji ve sulama projeleri ile iskân projelerinin gerçekleştirilmesi, yeni ormanların yetiştirilmesi, kıylların korunmast ve turizm " amaçlarıyla yapılacak kamulaştırmalarda, taksitlendirme süresinin beş yılı aşmaması, taksitlerin eşit olması ve taksitler için kamu alacaklarına uygulanan en yüksek faizin uygulanması kaydıyla kamulaştırma bedelinin taksitle ödenmesinin kararlaştırılabileceği kabul edilmiştir. Ancak kamulaştırılan taşınmazı doğrudan kendisi işleten küçük çiftçiye ait kamulaştırma bedelinin peşin ödenmesi gerekmektedir.

30 Kamulaştırma bedelinin nakden ödenmesi kuraldır. Ancak Kamulaştırma Kanunu'nun 26. maddesinde öngörülen usul ve esaslar doğrultusunda trampa yoluyla kamulaştırma yoluna başvurulabilir.

31 DURAN, s. 48; KALABALIK, s. 309; KUTLU, s. 43; GÜNDAY, s. 382, ONAR, CİLT III, s. 1709.

32 İdari irtifak, kamu yararı için veya kamusal alan lehine özel kişilere ait taşınmazlar üzerindeki mülkiyet hakkına getirilen sınırlamalardır. ARTUKMAÇ, s. 15; GÖZLER, s. 665; KUTLU, s. 63; ÖZYÖRÜK, s. 25; ÖZDAMAR, s. 324.

33 Taşınmazın kısmen kamulaştırılması veya taşınmaz üzerinde irtifak hakkı tesis edilmesi kamu yararını gerçekleştirmek için yeterliyken, taşınmazın bütününün kamulaştırılması konu ve amaç unsurları açısından hukuka aykırı olacaktır. Zira gerçek ihtiyaçtan fazla kamulaştırma yapıldığ 1 takdirde, fazladan kamulaştırılan kısım için kamu yararı bulunmamaktadır. AKYILMAZ/ SEZGINER/ KAYA, s. 600; KALABALIK, s. 315; ÖZYÖRÜK, s. 96. 
edilmektedir ${ }^{34}$. Her ne kadar hukukumuzda genel idari usul kanunu bulunmasa da, kamulaştırma işleminin gerek idari gerekse adli aşamasına ilişkin usul ve esaslar Kamulaştırma Kanunu'nda ayrıntılı olarak düzenlenmişti ${ }^{35}$. İdare, mülkiyet hakkının özüne dokunan bir müdahale niteliği taşıyan kamulaştırma yetkisini kullanırken anayasa ve kanunlarda öngörülen usul ve esaslara uygun davranmalı ve herhangi bir mağduriyete sebebiyet vermemeye gayret etmelidir.

\subsection{Kamulaştırmanın Aşamaları}

\subsubsection{Kamulaştırmanın İdari Aşaması}

İdari aşamada ilk olarak, idare tarafından kamulaştırma bedelini karşılamaya yetecek ödeneğin sağlanması gerekmektedir. Zira Kamulaştırma Kanunu'nun 3. maddesinin 4. fikrası, yeterli ödenek temin edilmeden kamulaştırma işlemlerine başlanmasına cevaz vermemektedir. Yeterli ödenek ile kastedilen "taşınmazın gerçek değerinin ödenmesi ölçütü dikkate alınarak belirlenecek tahmini bedeldir"36.

Yeterli ödenek temin edildikten sonra, Kamulaştırma Kanunu'nun 5. maddesi uyarınca tespit edilecek yetkili idare tarafından kamu yararı kararı alınması ve alınan bu kararın 6. maddede yer alan makamlar tarafindan onaylanması gerekmektedir. Zira "özel mülkiyet, bedeli, tam karşılı̆̆ı olarak ödense de, kamu yararı söz konusu olmadı̆̆ müddetçe feda edilemeyecek kişiye sıkı sıklya bağlı haklardandır"37. Kamu yararı karar $^{38}$ ile idarenin faaliyetlerini yürütebilmek için bir taşınmaza ihtiyacı olduğu belirlenmekte ${ }^{39}$ ve kamulaştırma yapması için idareye izin verilmektedir ${ }^{40}$. Dolayısıyla kamu yararı kararı, kamulaştırma işleminin sebep ve amaç unsurunu teşkil

\footnotetext{
34 DÜREN, s. 25; KALABALIK, s. 310; KIRATLI, s. 57;ÖZYÖRÜK, s. 138; “...Kamulaştırma işlemi daha önce teknik bir idari işlem iken, 2001'de, 2942 sayılı KK'da yapılan değişiklik sonucunda, adli süreç ile bütünleşen karma bir işlem niteliğine dönüşmüşü̈r..." KUTLU GÜRSEL, s. 1006.

35 KALABALIK, s. 300.

36 ATAY, s. 824; "Kamulaştırılacak taşınmazın bedelinin tespiti daha ilerideki aşamada belirlenebileceğinden buradaki ödenek herhalde tahmini bir bedel olacaktır" ŞAHIN, s. 625.

37 KIZIL (Erkelli), s. 210.

38 "Hangi hallerde kamu yararı olduğu, ekonomik ve sosyal gelişmelerle doğru orantıl olarak değişmektedir" DÜREN, s. 9.

39 ATAY, s. 824-825.

40 ÇAĞLAYAN, s. 455; ÇAKMAK, s. 472.
}

Ankara Hacı Bayram Veli Üniversitesi Hukuk Fakültesi Dergisi C. XXIV, Y. 2020, Sa. 1337 
eden ${ }^{41}$ soyut bir karardır ${ }^{42}$. Kamu yararı kararının alınmasıyla kamulaştırma işlemi, mülkiyet hakkı karşısında meşruiyet kazanmaktadır ${ }^{43}$. Kamulaştırma süreci neticesinde verilecek kamulaştırma kararı ile idarenin ihtiyaç duyduğu taşınmaz, sınırları, vasıfları, malik ve zilyetleriyle somutlaştırılacaktır ${ }^{44}$.

Kamuyararıkararınınalınmasıveonaylanmasındansonra,kamulaştırılacak taşınmaz ${ }^{45}$, ilgili taşınmazının durumu, malik veya zilyetlerinin tespit edilmesi gerekir (KK m. 7/1). Böylelikle idare, taşınmazı kısmen mi yoksa tamamen mi kamulaştıracağ $11^{46}$, ihtiyaç duyduğu taşınmazın kamulaştırılması sürecinde kimi veya kimleri muhatap alacağını belirlemektedir ${ }^{47}$. Diğer taraftan idare, ilgili vergi dairesinden kamulaştırılacak taşınmazın vergi beyan ve değerlerini isteyecektir. İlgili vergi dairesi, en geç bir ay içinde, taşınmazın vergi beyan ve değerini, vergi beyan ve değeri yok ise beyan yerine geçmek üzere takdir edilecek değeri idareye verecektir (KK m. 7/2).

Kamulaştırılacak taşınmazın tespit edilmesinden sonra, ilgili idare tarafından kamulaştırma kararı alınacak ve bu kararının tapu siciline şerh edilmesi taşınmaz malın kayıtlı olduğu tapu idaresine bildirilecektir (KK m. 7/3). Söz konusu tescil ile taşınmaz için alınan kamulaştırma kararından üçüncü kişilerin bilgilendirilmesi amaçlanmaktadır ${ }^{48}$. Şerh tarihinden itibaren

${ }^{41}$ GÖVEN, s. 258; GÜNAY, s. 258; KALABALIK, s. 301-311; KUTLU, s. 59; ŞAHİN, s. 625; TEZCAN, s. 380.

42 DÜREN, s. 30; KIZIL (Erkelli), s. 211.

43 İNCEOĞLU, s. 72.

44 AKYILMAZ/ SEZGINER/ KAYA, s. 604; ARTUKMAÇ, s. 31; KALABALIK, s. 311.

45 İdare kamulaştırılacak taşınmazı tespit ederken gerekli incelemeleri yapmalı, mevzuatta belirtilen usul ve esasları dikkate almalıdır. Danıștay 6. Dairesi, önüne gelen bir uyuşmazlıkta, madencilik faaliyetleri için kamulaştırılacak taşınmazın tespitinde idarenin gerekli araştırma ve tahlilleri yapmadığını ifade ederek bakanlık olurunu iptal etmiştir. Mahkeme iptal kararını şu gerekçelere dayandırmıştır: “... Öncelikle, kamulaştırılması istenen taşınmazın ... A.Ş'nin işletme ruhsatı içerisinde olup olmadığı, işletme ruhsatı içerisinde ise yukarıda anılan Yönetmelik hükmüne göre atık depolama havuzunun kaçıncı sinıf tesis olduğunun belirlenerek yerleşim yerlerine uzaklığının yeterli olup olmadı̆̆ının belirlenmesi gerekmektedir. Bu hususlar araştırıldıktan sonra, çevreye olası etkilerinin engellenmesine yönelik tedbirlerin alındiğg ileri sürülerek buna ilișkin bilgi ve belgeler sunulduğundan ek bilirkişi raporu alınarak tesisin yerleșim yerlerine, tarım arazilerine, yer altı sularına, bölgenin faunasına ve florasına, zarar vermeyecek tedbirlerin alınıp alınmadığının ortaya konulması suretiyle dava hakkında karar verilmesi gerekmektedir...” Danıştay 6. Daire, T. 25.09.2018, E. 2016/3777, K. 2018/ 7044, Kazanc1 İçtihat Bilgi Bankas1.

46 DÜREN, s. 34.

47 KIRBAŞ, s. 68.

48 Kamulaştırma kararının tapuya tescil edilmesi ne mülkiyetin idareye geçmesi sonucunu 
altı ay içinde, mahkemeden alınacak kamulaştırma bedelinin tespiti ve idare adına tescili talebinde bulunulduğuna dair belge tapu müdürlügüne sunulmaz ise kamulaştırma kararına ilişkin şerh tapu sicilinden resen silinecektir (KK m. 7/3).

İdare, ihtiyaç duyulan taşınmazı, kıymet takdir komisyonunun belirleyeceği bedel üzerinden -ancak komisyonca belirlenen tahmini bedel belirtilmeksizin- malikten satın alma yoluna öncelikle başvurmak zorundadır (KK m. 8/1). Uzlaşma komisyonu tarafindan yürütülecek müzakereler neticesinde malik ile anlaşma sağlanırsa, söz konusu anlaşma bir tutanak ile kayıt altına alınacaktır (KK m. 8/5). İdare, tutanakta kararlaştırılan bedeli hazır ederek malikten tapuda idare adına ferağ vermesini, tutanağın düzenlenmesinden itibaren en geç kırk beş gün içinde istemelidir (KK m. 8/6). Malikin tapuda ferağ vererek taşınmazın idare adına tescil edilmesi üzerine, kamulaştırma bedeli taşınmaz malikine ödenecek ve böylelikle ilgili taşınmaz adli aşamaya geçmeye gerek kalmaksızın kamulaştırılmış olacaktır.

KamulaştırmaKanunu'nun 8. maddesi kapsamında yürütülen müzakereler neticesinde, idarenin taşınmaz malikiyle bir anlaşmaya varamamış olması da mümkündür. $\mathrm{Bu}$ durumda kamulaştırılacak taşınmazın satın alma usulüyle elde edilmesi mümkün değildir. Dolayısıyla idarenin taşınmazın kendi adına tescili için adli süreci başlatması gerekmektedir.

\subsubsection{Kamulaştırmanın Adli Aşaması}

İdare, bir önceki başlıkta değinildiği üzere, kamulaştırılmasına karar verilen taşınmazı elde etmek için öncelikle malikle anlaşarak satın alma yoluna başvurmalıdır. Malikle yürütülecek müzakere neticesinde uzlaşma sağlanamaz ise idare, kamulaştırmanın idari aşamasına ilişkin belge ve tutanakları da ekleyerek bir dilekçe ile taşınmazın bulunduğu yer asliye hukuk mahkemesine başvuracak ve kamulaştırma bedelinin mahkemece tespit edilerek taşınmazın idare adına tesciline karar verilmesini talep edecektir (KK m. 10/1). İlgili asliye hukuk mahkemesi, idarenin başvurusundan itibaren en geç otuz gün sonrası için bir duruşma günü tespit edecek ve duruşma gününü, idarenin dilekçesini ve eklerinden birer örneği meşruhatlı davetiye ile malike tebliğ edecektir ${ }^{49}$ (KK m. 10/2). Yapılan araştırmalar neticesinde taşınmaz

doğurur ne de taşınmazın üçüncü kişilerce iktisabını engeller. AKYILMAZ/ SEZGİNER/ KAYA, s. 604; GÖZLER, s. 659; KUTLU, s. 98-99; ŞAHİN, s. 628.

49 Kamulaştırma Kanunu'nun 31. maddesine göre, 10. madde doğrultusunda mahkemece yapılan tebligat, davet ve ilanen tebligattan sonra, ilgili taşınmazın başkasına devir ve ferağ 
malikinin adresi bulunamazsa ilan yoluyla tebligat yapılacaktır. Ayrıca idareye de duruşma günü tebliğ edilmelidir (KK m. 10/2).

Malik, Kamulaştırma Kanunu'nun 14. maddesi uyarınca, tebligattan itibaren 30 günlük süre içerisinde, kamulaştırma işlemine karşı idari yargıda iptal davası açabilir. İptal davası açma hakkı yalnızca taşınmaz malikine tanınmıştır, zilyet ve diğer ilgililerin ise iptal davası açma hakkı bulunmamaktadır $^{50}$. Malik iptal davası açmadan önce, 2577 sayılı İdari Yargılama Usul Kanunu'nun 11. maddesi doğrultusunda idareye başvurma hakkına da sahiptir ${ }^{51}$.

Mahkeme tarafindan belirlenen ve taraflara tebliğ edilen duruşma gününde, hâkim öncelikle tarafları kamulaştırma bedeli konusunda anlaşmaya davet eder. Tarafların belli bir miktar üzerinde anlaşması durumunda söz konusu miktar kamulaştırma bedeli olarak kabul edilir (KK m. 10/5). Ancak taraflar arasında anlaşma sağlanamazsa hâkim, bilirkişi incelemesi ve keşif yaptırarak kamulaştırma bedelini kendisi tespit eder (KK m. 10/6-7-8).

Tarafların üzerinde anlaştıkları bedelin veya tarafların anlaşamaması durumunda hâkim tarafından tespit edilen kamulaştırma bedelinin, mahkemece belirlenen banka hesabına yatırılması ve yatırıldığına dair makbuzun mahkemeye verilmesi için idareye on beş günlük süre verilecektir (KK m. 10/8). Bu sürenin, bir defaya özgü olmak kaydıyla, gerekli durumlarda uzatılması mümkündür. Kamulaştırma bedelinin yatırıldığına dair makbuzun mahkemeye sunulması durumunda mahkeme, taşınmazın idare adına tescil edilmesine ve kamulaştırma bedelinin taşınmaz malikine ödenmesine karar

veya temliki yasaktır.

50 KAYA, s. 338; “...Ancak, 2942 Sayılı Kamulaştırma Kanununun Dava Hakkı bașlıklı 14. maddesinde, kamulaştırma işlemlerine karşı, kamulaştırmaya konu taşınmaz malın maliki tarafindan, iştirak halinde veya müssterek mülkiyette ise paydaşlar tarafindan dava açılabileceği vurgulanmış olduğundan, altın madeni sahasında acele kamulaștırılacak taşınmazı bulunmayan İzmir Su ve Kanalizasyon İdaresi Genel Müdürlüğü'nün, davacının taşınmazının acele olarak kamulaştırılmasına dair işlemlerin iptali istemiyle dava açmasına hukuken olanak bulunmamaktadır. Her ne kadar, Danıştayın yerleşik kararlarında, çevre, tarih ve kültürel değerlerin korunması, imar uygulamaları gibi kamu yararını ilgilendiren konularda dava açma ehliyeti genis yorumlanarak, özellikle yörede ikamet eden vatandaşların da dava açma ehliyetlerinin bulunduğunun kabul edildiği görülmekte ise de, kamulaştırma ve acele kamulaștırma işlemlerinin mülkiyet hakkına müdahale niteliğinde olmaları sebebiyle kamu yararını değil bireysel yararı ilgilendirdiği açıktır..." Danıştay İdari dava Daireleri Genel Kurulu, T. 19.04.2012, E. 2009/1936, K. 2012/500, Kazanc1 İçtihat Bilgi Bankası.

51 AKYILMAZ/ SEZGINER/ KAYA, s. 606. 
verecektir. Mahkemece verilen tescil kararı kesin olup, aleyhine istinaf veya temyiz yoluna başvurulamaz. Ancak taraflar bedele ilişkin karar aleyhine istinaf veya temyiz yoluna başvurabileceklerdir (KK m. 10/8).

\section{2. İdarenin Kamulaştırmadan Vazgeçmesi}

Kamulaştırma bir idari işlemdir. Dolayısıyla idari işlemlerin geri alınmasına ilişkin genel kurallar uyarınca geri alınabilecektir ${ }^{52}$. Ancak kamulaştırılan taşınmaz idarenin mülkiyetine, kamulaştırma bedeli ise mal sahibinin malvarlığına dâhil olduğu için kamulaştırma işleminin geri alınmasının özel olarak düzenlenmesi ihtiyacı doğmuştur ${ }^{53}$. Keza idare, kamulaştırma işlemlerinde herhangi bir hukuka aykırılık söz konusu olmasa da taşınmaz için takdir edilen kamulaştırma bedelini yüksek bulması, mali imkânsızlık gibi nedenlerle kamulaştırmadan vazgeçebilir ${ }^{54}$. Dolayısıyla Kamulaştırma Kanunu'nun 21 ve 22. maddelerinde kamulaştırmadan vazgeçme usulü düzenlenmiştir.

İdarenin kamulaştırmanın her aşamasında ${ }^{55}$, kamulaştırma kararını veren ve onaylayan yetkili merciin kararıyla kamulaştırmadan tek taraflı olarak kısmen veya tamamen vazgeçmesi mümkündür (KK m. 21). Dava sırasında kamulaştırmadan vazgeçilmesi halinde idare yargılama giderlerine mahkûm edilecek ve mal sahibi tekrar taşınmazına kavuşacaktır ${ }^{56}$. Bu madde ile kamulaştırmadan vazgeçme hakkı yalnızca kamulaştırma kararı veren idareye tanınmıştır ${ }^{57}$.

Kamulaştırma Kanunu'nun 22. maddesi ise kamulaştırmanın kesinleşmesinden sonra idarenin vazgeçmesi durumunda uygulanacak usulü düzenlemektedir. $\mathrm{Bu}$ hüküm uyarınca idare, kamulaştırmanın

52 GÜNDAY, s. 274.

53 GÖZLER, s. 664; ONAR, CILTT III, s. 1569.

${ }^{54}$ DÜREN, s. 77.

55 "Kamulaştırma Kanunu'nun 21. maddesinde yer alan "kamulaştırmanın her safhası" ifadesi ile kamulaştırılacak taşınmazın idare adına tesciline kadarki süreç anlaşılmalıdır" YILDIRIM, s. 9.

56 AKYILMAZ/ SEZGINER/ KAYA, s. 608.

57 Yargitay Hukuk Genel Kurulu, T. 25.09.2002, E. 2002/18-620, K. 2002/649, Kazanc1 İçtihat Bilgi Bankas1. 
kesinleşmesinden ${ }^{58}$ itibaren beş yıl içinde ${ }^{59}$ taşınmaza ihtiyaç kalmaması haline kamulaştırmadan vazgeçebilecektir. Taşınmazın kamulaştırma amacına veya kamu yararına olmak kaydıyla başka bir ihtiyaca tahsis ${ }^{60}$ edilmemesi, idarenin taşınmaza ihtiyacının kalmadığını göstermektedir. Bunun üzerine idare, taşınmaza ihtiyacının kalmadığını ve isterlerse taşınmazı geri alabileceklerini mal sahibine veya mirasçılarına bildirmek zorundadır ${ }^{61}(\mathrm{KK}$ m. 22/1). İdarenin bu hususta takdir yetkisi bulunmamaktadir ${ }^{62}$.

İdarece yapılan bildirim üzerine, mal sahibi veya mirasçıları kamulaştırılan taşınmazı geri almak isterlerse, bildirim tarihinden itibaren üç ay içinde, aldıkları günden itibaren işleyecek kanuni faiziyle birlikte kamulaştırma bedelini iade etmeleri gerekmektedir (KK m. 22/1). Üç aylık süre, hak düşürücü süre niteliği taşımaktadır ${ }^{63}$. Mal sahibi veya mirasçıları, idarenin teklifini kabul edip etmeme hususunda serbestiye sahiptir.

Kamulaştırılan taşınmaza kamulaştırmayı yapan idare dışında bir başka idarenin ihtiyaç duyması durumunda, 22. madde hükmü uygulanmayarak Kamulaştırma Kanunu'nun 30. veya 1050 sayılı Muhasebei Umumiye

58 Kamulaştırma kararının kesinleşmesi, kamulaştırma satın alma usulü ile yapılmışsa anlaşma tutanağının imzalanmasıyla, anlaşma sağlanamazsa asliye hukuk mahkemesi tarafından verilen tescil kararıyla gerçekleşmektedir. AKYILMAZ/ SEZGINER/ KAYA, s. 608.

59 Kamulaştırma Kanunu'nun 22. maddesinin 3. fikras1 "Bu madde hükümleri, kamulaştırmanın kesinleşmesi tarihinden itibaren beş yıl geçmiş olması hâlinde uygulanmaz" şeklindedir.

60 ONAR'a göre tahsis, "bir Devlet malını umumun faydalanmasina koyan veya bir âmme hizmetine bağlayan, diğer tâbirle, hususî emlâki, orta malı veya hizmet malı kategorisine koyan veya âmme hizmetinin vasıtası haline getiren îdari bir tasarruftur". ONAR, Cilt II, s. 1340-1341.

61 “... Davalı ..., dava konusu 18 ada 66 parselden 2008 yılında yapılan imar uygulaması sonucu ifrazen oluşan 24.695,60 m2 yüzölçümlü 2084 ada 1 parsel yönünden kamu yararı kararında belirtilen amacı gerçekleştirmediği gibi bu taşınmazı kamu yararı amacı doğrultusunda kullanmayarak 2942 Sayılı Kamulaştırma Kanununun 22. maddesi uyarınca taşınmazın kamulaștırma amacına veya kamu yararına yönelik herhangi bir ihtiyaca tahsisi lüzumu kalmaması halinde keyfiyetin idarece mal sahibine veya mirasçılarına 7201 Sayılı Tebligat Kanunu hükümlerine göre duyurulmasına ilişkin yükümlülüğü yerine getirmeden bu taşınmazı özel kişilere devrederek davacı idarenin mülkiyet hakkına kamulaştırmanın dayandığ kamu yararı amacı bulunmadan müdahale edilerek Anayasanın 35. maddesindeki güvencelere aykırı olarak mülkiyet hakkını ihlal etmiştir..." Yargıtay 5. Hukuk Dairesi, T. 20.10.2018, E. 2017/13781, K. 2018/25577, Kazancı İçtihat Bilgi Bankas1.

62 YILDIRIM, s. 14.

${ }^{63}$ SOLMAZ, s. 72; “...Kamulaştırma Kanunu'nun 22. maddesinde öngörülen 3 aylı süre hak düşürücü bir süredir. Bu süre içerisinde bedeli yatırmayan malikin geri almaktan kaçındığ kabul edilmelidir...” Yargitay Hukuk Genele Kurulu, T. 08.10.1997, E. 1997/7-519, K. 1997/788, Kazancı İçtihat Bilgi Bankası. 
Kanunu $^{64}$ 'nun 23. maddesi uyarınca işlem yapılacaktır (KK m. 22/4). $\mathrm{Bu}$ hüküm ile idarenin taşınmazlarından en uygun şekilde yararlanılması amaçlanmaktadır ${ }^{65}$.

\subsection{Mal Sahibinin Geri Alma Hakkı}

Kamu yararı kararında belirtilen sebebin gerçekleşmemesi veya gerçekleşme imkânının ortadan kalması durumunda, kamulaştırılan taşınmazın malikinin veya mirasçılarının taşınmazı geri alma hususunda kazandığı hakka mal sahibinin geri alma hakkı denilmektedir ${ }^{66}$. Kamulaştırmayı düzenleyen Anayasa'nın 46. maddesinde, mal sahibinin geri alma hakkına ilişkin herhangi bir düzenleme yer almamaktadır. Geri alma hakkı esas olarak Kamulaştırma Kanunu'nun 23. maddesinde düzenlenmektedir. Ancak Anayasa Mahkemesi, bazı kararlarında geri alma hakkını anayasal bir hak olarak nitelendirmektedir ${ }^{67}$. Zira kamu yararı kararında belirtilen sebebin gerçekleşmemesi veya gerçekleşme ihtimalinin ortadan kalması halinde, kamulaştırma işlemi hukuki dayanaktan yoksun kalacaktır. Bu durumda mal sahibine taşınmazı geri alma hakkının tanınması, hukuk devleti ilkesinin sonuçlarından biridir ${ }^{68}$.

Kamulaştırma Kanunu'nun 23. maddesi uyarınca, mal sahibini geri alma hakkının doğabilmesiiçinüçşartıngerçekleşmesigerekmektedir:Kamulaştırma bedelinin kesinleşmesi ${ }^{69}$, kamulaştırma bedelinin kesinleşmesinden itibaren

64 09.06.1927 tarih ve 606 say1l Resmi Gazete.

65 SOLMAZ, s. 80.

${ }^{66}$ ARTUKMAÇ; s. 135; ATAY, s. 838; GÖZLER, s. 664; GÜNDAY, s. 271.

67 “...Anayasa yalnız sözü ile değil, özü ile de bir takım kurallar koyan ve yine Anayasa'nın koyduğu açık kuralın dayandığ hukuk ilkeleri dahi, Anayasa kuralı gibi bağlayıcıdır. Burada gerek 38. Maddenin yazllışında ve kabul edilmesindeki zorunluluktan, gerekse 36 ve 38. Maddelerin birlikte incelemesinden belirdiği üzere kamulaștırılan malın kamu yararına uygun kullanılmaması durumunda eski mal sahibine geri verilmesinin Anayasal bir gerek olduğu ortaya çıkmaktadır...” Anayasa Mahkemesi, T. 25.10.1969, E. 1967/41, K. 1969/57, 12.3.1971 tarih ve 13776 sayılı Resmi Gazete; Geri alma hakkının, malikin önceki mülkiyetine bağlı bir hak olduğu ve Anayasa'nın 35. maddesi kapsamında incelenmesi gerektiğine dair karar için bkz. Anayasa Mahkemesi, T. 14.05.2015, E. 2014/177, K. 2015/49, 11.06.2015 tarih ve 29383 say1lı Resmi Gazete.

68 SOLMAZ, s. 12; Kamulaştırmanın beş yıllık süreyle kısıtlanmasının kamu yararına uygun sonuçlar doğurmayacağına ilişkin görüş için bkz. DÜREN, s. 80-82.

${ }^{69}$ Kamulaştırma bedelinin asliye hukuk mahkemesinin kararıyla belirlendiği durumlarda kamulaştırma bedeli, karara karşı süresi içinde yargı yoluna başvurulmaması durumunda bu sürenin dolmasıyla, karara karşı süresi içinde yargı yoluna başvurulmuş ise yarg1 yolunda yapılan inceleme neticesinde verilen kararın tebliği ile kesinleşmektedir. AKYILMAZ/ SEZGINER/ KAYA, s. 610; Kamulaştırma satın alma usulüyle yapılmışsa, kamulaştırma 
beş yıl geçmesi ve beş yıllık süre içerisinde, taşınmaz üzerinde kamulaştırma amacı doğrultusunda hiçbir işlem veya tesisat yapılmaması veya taşınmazın kamu yararına yönelik başka bir ihtiyaca tahsis edilmeyerek olduğu gibi birakılmas1.

23. maddede öngörülen şartların gerçekleşmesi üzerine, mal sahibi veya mirasçıları, kamulaştırma bedelini aldıkları tarihten itibaren işleyecek faizi ile birlikte iade ederek kamulaştırılan taşınmazı geri alma hakkına sahiptir. Ancak söz konusu geri alma hakk1, beş y1llı sürenin bitiminden itibaren bir yıl içinde kullanılmalıdır. Zira bir yıllık süre, hak düşürücü süre niteliğinde olup $^{70}$, bu süre içinde kullanılmayan geri alma hakkı ortadan kalkacaktır. Beş ve bir yıllık süreler geçtikten sonra, mal sahibi veya mirasçılar idareden hak, bedel veya tazminat talebinde bulunamayacaktır (KK m. 23/3).

\section{MADEN HUKUKUNDA KAMULAŞTIRMA USULÜ}

Madencilik faaliyetleri, altyapısı hazırlanmış bir alanda değil, madenin bulunduğu alanda yürütülmek zorunda olup ${ }^{71}$ yer seçim şans1 bulunmamaktadir ${ }^{72}$. Belirli bir alanda madencilik faaliyetlerinde bulunmak isteyen kişiler, idareye başvurarak arama veya işletme ruhsatı almalıdırlar. Ancak maden arama veya işletme ruhsatı almak, ruhsat sahibine ruhsata konu alan üzerinde doğrudan madencilik faaliyetlerine başlama konusunda bir yetki vermemektedir ${ }^{73}$. Zira ruhsat alanı genellikle ruhsat sahibi dışında başka bir özel hukuk kişisinin mülkiyetinde yer almaktadır ${ }^{74}$. Dolayısıyla

bedelinin kesinleşmesi kamulaştırmanın kesinleşmesiyle birlikte gerçekleşmektedir. SOLMAZ, s. 89 .

70 SOLMAZ, s. 106.

71 FINDIKLIGİL s. 100; GÜLAN, (2008), s. 231-232; TBMM, s. 100.

72 ÇAĞATAY/ ALİEFENDİOĞLU, s. 224.

73 “...Somut olayda, davalı şirket tarafindan davacı ile aralarında düzenlenen ve çekişmeli taşınmazı kullanmasını haklı kılan sözleșme, vs. sunulmamış ve bu yönde bir savunma yapılmadı̆̆ gibi kamu yararı kararı alındığına ve kamulaștırdığına dair de bir bulgunun varlığı kanıtlanmış değildir. Öyleyse, sadece maden işletme ruhsatı alınmış olmasının çekişmeli taşınmazın tasarrufu yönünde ruhsat sahibine bir hak bahşetmeyeceği tartışmasızdır...”, Yargitay 1. Hukuk Dairesi, T. 25.02.2010, E. 2010/334, K. 2010/2074, Kazancı İçtihat Bilgi Bankası; “...Yetkili mercilerden alınmış olsa dahi maden işletme ruhsatı hukuk devletinde kutsal olduğu kabul edilen özel mülkiyete el atma hakkını vermez. Bu yasal düzenlemeler çerçevesinde olaya bakıldığında, davalı şirketin davacıların paydaşı olduğu taşınmazda hışır madeni çıkarmak suretiyle taşınmaza haksız olarak el attı̆̆ı, taşınmazın tamamen kullanılamaz hale geldiği dosya kapsamı ile sabittir... "Yargıtay 1. Hukuk Dairesi, T. 05.03.2009, E. 2009/1430, K. 2009/2785, Kazanc1 İçtihat Bilgi Bankası.

74 GÜNAY, s. 105.

344 Ankara Hacı Bayram Veli Üniversitesi Hukuk Fakültesi Dergisi C. XXIV, Y. 2020, Sa. 1 
ruhsat sahibine, madencilik faaliyetlerinde bulunabilmesi için ruhsat alanında kısmen veya tamamen tasarruf yetkisinin tanınmas gerekmektedir $^{75}$.

Maden Kanunu'nun 46. maddesiyle, ruhsat sahibinin madencilik faaliyetlerinde bulunabilmesi için ruhsata konu alanda ${ }^{76}$ kendisine irtifa ve/ veya intifa hakkı tesis edilmesini veya ruhsat alanının kamulaştırılmasını talep etme hakkı tanınmıştır. Gerek arama döneminde gerekse işletme döneminde ruhsat alanı üzerinde ruhsat sahibi lehine irtifak hakk $1^{77}$ tesis edilebilecektir ${ }^{78}$. Zira Kamulaştırma Kanunu'nun 4. maddesi uyarınca, "amaç için yeterli olduğu takdirde taşınmaz malın belirli kesimi, yüksekliği, derinliği veya kaynak üzerinde kamulaştırma yoluyla irtifak hakkı kurulabilir". Ancak bazı durumlarda madencilik faaliyetlerinde bulunmak isteyen ruhsat sahibi lehine ruhsat alanı üzerinde irtifak ve/veya intifa hakk1 tesis edilmesi, ihtiyacı karşılamakta yetersiz kalmakta ve taşınmazın kısmen veya tamamen kamulaştırılması bir gereklilik haline gelmektedir ${ }^{79}$.

Maden hukuku kapsamında kamulaştırma, Maden Kanunu'nun 3. maddesine göre "işletme ruhsat süresi boyunca ruhsat alanında kalan özel mülkiyet arazilerine madencilik faaliyeti için alınan kamulaştırma kararl"; Maden Yönetmeliği'nin (MY $)^{80}$ 4. maddesinin çç bendinde göre, "işletme ruhsat süresi boyunca ruhsat alanında kalan özel mülkiyet arazilerinde yapılacak madencilik faaliyeti için alınan kamu yararı kararı ve

75 ÇEVIKÇELİK, s. 141; GÖĞER, s. 136; Ruhsat alanında hareket etme hakkı kendisine tanınmadan madencilik faaliyetlerine başlayan şirkete uygulanan idari yaptırım kararı aleyhine açılan iptal davası, Danıştay 8. Dairesi tarafından reddedilmiş ve idari işlem hukuka aykırı görülmemiştir. Danıştay 8. Daire, T. 12.11.1992, E. 1992/244, K. 1992/2781, Kazancı İçtihat Bilgi Bankası.

76 “...Maden Kanunu’nun 46. maddesinde belirtilen irtifak hakks tesisine ilişkin düzenlemenin özel mülkiyete konu taşınmazlara yönelik olduğu, bu düzenlemeye dayalı olarak kamu idarelerine ait taşınmazlar üzerinde irtifak hakkı tesis edilemeyeceği açıktır...” Danıştay 8. Daire, T. 18.02.2014, E. 2010/4154, K. 2014/1039, Kazanc1 İçtihat Bilgi Bankas1.

77 Ruhsat sahibi lehine tesis edilecek irtifak, idari irtifak niteliğini taşımaktadır. Zira Enerji ve Tabi Kaynaklar Bakanlığı, Anayasa'nın 46. maddesi uyarınca idari bir işlemle irtifak kurmaktadır. TOPALOĞLU, (2015), s. 77.

78 ÇEVIKÇELIK, s. 144.

79 GÜLAN'a göre, madencilik faaliyetleri açısından kamulaştırma yerine irtifak ve/veya intifa hakk1 tesis edilmesinin isabetli olup olmayacağı araştırılmalıdır. GÜLAN, (2008), s. 204; SOLMAZ'a göre, madencilik faaliyetlerinde kamu yararı amacı belirli sürelerde geçerli olduğu için, kamulaştırma yerine irtifak hakkı tesis edilmesi yoluna başvurulması hakkaniyete uygun olacaktır. SOLMAZ, s. 18.

80 21.09.2017 tarih ve 30187 sayıl1 Resmi Gazete.

Ankara Hacı Bayram Veli Üniversitesi Hukuk Fakültesi Dergisi C. XXIV, Y. 2020, Sa. 1345 
4/11/1983 tarihli ve 2942 sayll Kamulaştırma Kanunu gereğince işlemlerin sonuçlandırılmasını" ifade etmektedir.

Madenler gerek 4721 say1lı Türk Medeni Kanunu'nun 704. maddesinde taşınmazlar arasında sayılmamaları, gerekse Anayasa ve Maden Kanunu uyarınca devletin hüküm ve tasarrufu altında olmaları nedeniyle doğrudan kamulaştırma işleminin konusu oluşturamazlar. Ancak madenin bulunduğu taşınmazın özel hukuk kişisinin mülkiyetinde olması halinde, söz konusu taşınmazın kamulaştırılması mümkündür.

Ruhsat alanlarının kamulaştırılması hususunda Maden Kanunu'nun 46. maddesi ile birtakım özel düzenlemeler yapılmış ve kamulaştırma işlemlerinin Kamulaştırma Kanunu'nda belirtilen usul ve esaslar doğrultusunda yapılacağ 1 ifade edilmiştir. Maden Kanunu'nun 46. maddesinde öngörülen kamulaştırma usulü, özel kişiler lehine yapılacak kamulaştırmanın tipik bir örneğini teşkil etmektedir.

Özel hukuk kişileri, kamu yararını gerçekleştirmeyi amaçladıkları durumlarda dahi doğrudan kamulaştırma yapma yetkisine sahip değildir ${ }^{81}$. Zira Anayasa'nın 46. maddesiyle kamulaştırma yapma yetkisi yalnızca devlet ve kamu tüzel kişilerine verilmiştir. Dolayısıyla özel hukuk kişileri tarafından alınan kamulaştırma kararları yok hükmündedir ${ }^{82}$. Ancak bazı durumlarda özel kişiler tarafından yürütülen faaliyetlerin sağladığı kamu yararı sebebiyle, özel kişiler -örneğin; kamu hizmeti imtiyazcısı, petrol hakk1 sahibi, maden işletme ruhsatı sahibi- lehine kamulaştırma yapılması mümkündür ${ }^{83}$.

Kamulaştırma Kanunu'nun 1. maddesinin 2. fikras1, “özel kanunlarına dayanılarak gerçek ve özel hukuk tüzelkişileri adına yapılacak kamulaştırmalarda da, bu Kanun hükümleri uygulanır" şeklindedir. Dolayısıyla devlet veya kamu tüzel kişileri tarafindan özel kişiler lehine kamulaştırma yapılabilmesi, bu hususta ilgili özel kanunda açık bir hükmün

81 KUTLU GÜRSEL, s. 1007.

82 “...kamu kurumu olmayıp özel hukuk tüzel kişisi olan İzmir Yüksek İslam Enstitüsü Yaptırma ve Koruma Derneğinin özel yasa hükmü bulunmaksızın okul yeri kamulaştırma kararı alması açıkça yasaya aykırıdır, hiçbir hukuki değer taşımaz. Bu nedenle dava konusu kamulaştırma kararının hükümsüz (yok) sayılmasına ... ”, Danıştay 6. Dairesi, T. 13.05.1981, E. 1980/1388, K. 1981/1547, Danıştay Dergisi, 1982, S. 44-45, s. 259.

83 AKYILMAZ/ SEZGINER/ KAYA, s. 597; ARTUKMAÇ, S. 24; ATAY, s. 810-811; GÜNDAY, s. 252; KUTLU, s. 58. 
varlığını gerektirmektedir ${ }^{84}$. Özel kanunla herhangi bir yetkilendirme olmaksızın devlet veya kamu tüzel kişileri tarafından özel kişiler lehine yapılacak kamulaştırmalar ise yetki unsuru bakımından hukuka aykırı bir nitelik taşıyacaklardır ${ }^{85}$.

Özel kişiler lehine yapılacak kamulaştırmalarda temel amaç kamu yararının gerçekleştirilmesidir. Diğer bir ifadeyle, özel hukuk kişileri tarafından kamu hizmetlerinin yürütülmesi esnasında ihtiyaç duyulan taşınmaz mallar, özel hukuk kişileri yararına değil kamu yararı için kamulaştırılmaktadır ${ }^{86}$. Anayasa'nın 35. maddesi, mülkiyet hakkının yalnızca kamu yararı amacıyla sınırlandırılmasına cevaz vermektedir. Zira, kamu yararı kamulaştırmayı meşrulaştırmaktadır ${ }^{87}$. Dolayısıyla özel hukuk kişileri lehine yapılacak kamulaştırmalarda da kamu yararı kararının alınması bir zorunluluktur ${ }^{88}$.

Özel hukuk kişileri lehine kamulaştırmalarda kamu yararı kararı vermeye yetkili makam, özel hukuk kişisinin yürüttügü hizmet açısından denetime bağlı oldukları köy, belediye, il özel idaresi veya bakanlıktır (KK m. 5/1-c). Kamu yararı kararı verecek olan makam, resen harekete geçme imkânına sahip değildir. Dolayısıyla lehine kamulaştırma yapılan kişi gerçek kişi ise bu kişinin, özel hukuk tüzel kişisi ise tüzel kişinin yönetim kurulu veya idare meclisinin, yoksa yetkili yönetim organlarının kamu yararı kararı vermeye yetkili olan idareye başvurmaları gerekmektedir. Bu madde kapsamında köy, belediye veya il özel idare tarafından verilen kamu yararı kararı vali

84 GÖZLER, s. 649; KALABALIK, s. 313; “...Maddedeki "Hususi şahıslar lehine mahsus kanunlarına müsteniden yapılacak istimlâkler" deyimi bu konuda herhangi bir tereddüde yer bırakmıyacak açıklık ve kesinliktedir. Özel kanunu yetki vermiyorsa, özel kişiler yararına dâva konusu hükme dayanılarak kamulaştırmaya gidilmesi düşünülemiyeceği gibi bu hüküm bulunmasa, yahut kaldırılmış veya iptal edilmiş olsa dahi özel kanunun verdiği kamulaş̧tırma yetkisi yürürlükte kaldıkça kamulaştırma hükmünün işleyeceğinde şüphe yoktur...” Anayasa Mahkemesi, T. 28.12.1965, E. 1963/66, K. 1965/67, 19.4.1966 tarih ve 12278 sayıl1 Resmi Gazete.

85 SOLMAZ, s. 24.

86 KUTLU, s. 59; TOPALOĞLU, (2011), s. 328; “...Yukarıda yer verilen açılklamalar doğrultusunda, 3213 Sayll Maden Kanunu uyarınca yapılacak olan kamulaştırma işlemlerinde acele kamulaştırma yoluna başvurulabilmesi için, işletme sahibi özel girişimcinin yararının değil, belli süreli maden işletme çalışmaları konusunda gerçekleşecek olan kamu yararının karşılanması gereksiniminin, taşınmaz malikinin yararından üstün olması ve acelelik koşulunun kamu düzenine dair olması gerekmektedir..." Danıştay İdari Dava Daireleri Genel Kurulu, T. 10.04.2012, E. 2009/1936, K. 2012/500, Kazancı İçtihat Bilgi Bankası.

87 GÖVEN, s. 247.

88 KAYA, S. 98-99; KUTLU, s. 57; ÖZYÖRÜK, s. 140.

Ankara Hacı Bayram Veli Üniversitesi Hukuk Fakültesi Dergisi C. XXIV, Y. 2020, Sa. 1347 
tarafindan onaylanacaktır (KK m.7/1-h). Cumhurbaşkanı ve bakanlıklar tarafindan verilecek kamu yararı kararlarının ise onaylanmasına gerek yoktur (KK m.7/2).

\subsection{3 sayılı Maden Kanunu'nun 46. Maddesinde Öngörülen Kamulaştırma Usulünün Kapsamı}

Maden Kanunu'nun 46. maddesinde öngörülen ruhsat alanının kamulaştırılması usulünün uygulama alanı, yine aynı maddede yer alan bazı hükümlerle sınırlandırılmıştır.

Kanun'un 46. maddesinin 11. fikrası "I. Grup madenler ve micır ile kaba inşaat, baraj, gölet, liman, yol gibi yapılarda kullanılan her türlü yapı hammaddesi için kamulaştırma hükümleri uygulanmaz" şeklindedir. Bu hüküm uyarınca, maden hukukuna özgü kamulaştırma yoluna, Kanun'un 2. maddesinde yer alan bütün maden ve maden grupları açısından başvurulamayacaktır.

Maden Kanunu'nun 2. maddesinde madenler I. grup, II. grup, III. grup, IV. grup ve V. grup şeklinde bir ayrıma tabi tutulmuştur ${ }^{89}$. I. grubun kapsamına giren madenler Kanun'un 2. maddesinde “a) inşaat ile yolyapımında kullanılan ve tabiatta doğal olarak bulunan kum ve çakll” ve "b) tuğla-kiremit kili, çimento kili, marn, puzolanik kayaç (tras) ile çimento ve seramik" şeklinde sayılmıştır. Kanun'un 46. maddesinin açık hükmü gereğince, I. grup madenler açısından kamulaştırma yoluna başvurulamayacaktır. II. grup, III. grup, IV. grup ve V. grup madenler içinse "mıcır ile kaba inşaat, baraj, gölet, liman, yol gibi yapılarda kullanılan her türlü yapı hammaddesi” hariç olmak kaydıyla kamulaştırma yoluna başvurulması mümkündür. Kamulaştırma imkânının belirli maden ve maden grupları ile sınırlandırılmasının temel sebebi, diğer madenlere kıyasla daha yaygın bulunan madenler için kişilerin Anayasa'nın 35. maddesinde güvence altına alınan mülkiyet hakkına müdahalede bulunulmasının önlenmesidir ${ }^{90}$. Diğger bir ifadeyle kanun koyucu, diğer maden gruplarına kıyasla doğada yaygın bulunan, katma değeri düşük ve başka bir bölgeden kolayca sağlanması mümkün ${ }^{91}$ madenler açısından kamulaştırma usulüne başvurulmasında kamu yararı olmadığını zımni bir şekilde ifade etmiştir. Dolayısıyla "I. Grup madenler ve mıcır ile kaba inşaat, baraj,

\footnotetext{
89 Söz konusu maden gruplarının kapsamı için bkz. 7. dipnot.

90 ÇANGA, s. 401.

91 TOPALOĞLU, (2011), s. 329.
}

348 Ankara Hacı Bayram Veli Üniversitesi Hukuk Fakültesi Dergisi C. XXIV, Y. 2020, Sa. 1 
gölet, liman, yol gibi yapılarda kullanılan her türlü yapı hammaddesi” için madencilik faaliyetlerinde bulunmak isteyen ruhsat sahipleri, taşınmaz maliki ile anlaşmak zorundadır ${ }^{92}$. Aksi halde Enerji ve Tabii Kaynaklar Bakanlığı'nın kamu yararı kararı alarak kamulaştırma işlemlerine başlama hususunda bir yetkisi bulunmamaktadır ${ }^{93}$.

Maden Kanunu'nda 7020 sayılı Bazı Alacakların Yeniden Yapılandırılması ile Bazı Kanunlarda ve Bir Kanun Hükmünde Kararnamede Değişiklik Yapılmasına Dair Kanun" ${ }^{94}$ ile yapılan değişiklik ile "maden bölgesi" kavramı mevzuatımıza girmiştir. Maden bölgeleri "birbirine bitişik veya yakın maden sahalarında, yapılan üretimin çevresel etkileri, şehirleşme, işletme güvenliği, rezervin verimli işletilmesi ve benzeri sebeplerden dolayl yapllacak proje ve planlama çerçevesinde Genel Müdürlügün teklifi ve Bakan onayt ile" ilan edilebilmektedir (MK m. 29/7). Kanun'un 46. maddesinin 11. fikrasından farklı olarak, maden bölgesinde özel hukuk kişisi ruhsat sahibi lehine yapılacak kamulaştırmalarda maden ve maden grupları açısından bir sınırlama bulunmamaktadır. Diğer bir ifadeyle maden bölgesi ilan edilen alanlarda bütün maden gruplarına dair işletme ruhsatları için kamulaştırma yoluna başvurulabilecektir (MK m. 29/13).

Maden hukukuna özgü kamulaştırma usulünün bir diğer sınırı Maden Kanunu'nun 46. maddesinin 5. fikrasında yer almaktadır. İlgili hüküm "işletme ruhsatı safhasinda işletme faaliyetleri için gerekli olan özel mülkiyete konu taşınmaz, taraflarca anlaşma sağlanamaması ve işletme ruhsatı sahibinin talebi üzerine Bakanlıkça kamu yararı bulunduğuna karar verilmesi halinde kamulaştırılır" şeklindedir. Maden Yönetmeliği'nin 74. maddesinin ilk fikrasında da aynı hüküm tekrarlanmıştır.

Kanun'un 46. maddesinde öngörülen kamulaştırma yoluna, yalnızca işletme ruhsatı aşamasında ve işletme faaliyetleri için gerekli taşınmazlar açısından başvurulabilecektiri ${ }^{95}$. Diğer bir ifade ile işletme ruhsatının alınması ve işletme faaliyetleri için ihtiyaç duyulması, kamulaştırma talep etme hakkının ön şartını teşkil etmektedir ${ }^{96}$. Dolayısıyla işletme ruhsatı alınmış olsa

\footnotetext{
92 Danıştay 8. Daire, T. 25.02.2014, E. 2013/5309, K. 2014/1273, Lexpera Hukuk Bilgi Sistemi.

93 ÇİTİL, s. 206.

94 27.05.2017 tarih ve 30078 sayıl1 Resmi Gazete.

95 ÇEVIKKÇELIK, s. 147; TELLİ, s. 108-109.

96 ÖZTOPRAK, s. 93.
} 
dahi, söz konusu ruhsat alanında işletme döneminde yürütülmek istenen arama faaliyetleri için bu madde kapsamında kamulaştırma yoluna gidilemeyecektir ${ }^{97}$. Kanun'un açık hükmü gereğince, arama ruhsatı aşamasında kamulaştırma yoluna başvurma imkânı bulunmamaktadır ${ }^{98}$. Ruhsat sahibi, arama döneminde özel mülkiyete konu ruhsat alanında arama faaliyetlerinde bulunmak için Maden ve Petrol İşleri Genel Müdürlügü̈'ne müracaat ederek irtifak ve/veya intifa hakk1 tesisi talep etmelidir ${ }^{99}$.

Maden Kanunu'nun 3. maddesinde ve Maden Yönetmeliği'nin 4. maddesinde yer alan tanımlamalarda kamulaştırmanın ruhsat alanında kalan özel mülkiyete tabi taşınmazlar için mümkün olduğu ifade edilmiştir. Ancak gerek Kanun'da gerekse Yönetmelik'te kamulaştırmayı düzenleyen hükümlerde işletme faaliyetlerinin yürütülmesi için gerekli olan özel mülkiyete tabi taşınmazların kamulaştırılacağı belirtilmiştir. Mevzuatta yer alan iki farklı ifade, işletme ruhsat alanının dışında yer alan ancak işletme faaliyetleri için gerekli olan taşınmazlar da kamulaştırılabilecek midir, sorusunu da beraberinde getirmiştir.

TOPALOĞLU'na göre, işletme faaliyetlerinin yürütülmesi noktasında gerekli olan bütün özel mülkiyete konu taşınmazlar kamulaştırılabilecektir ${ }^{100}$. Ancak Kanun'un 24. maddesinin 4. fikrasi uyarınca, "arama ruhsatll sahalara, geçici tesis alanı ile arama süresince belirlenen görünür vel veya muhtemel rezerv alanı üzerine, arama ruhsatının diğer kısımları taksir edilerek, işletme ruhsatı verilir". İşletme faaliyetlerinin yürütüleceği temel alan işletme ruhsat alanıdır. Dolayısıyla Anayasa'nın 35. maddesinde düzenlenen mülkiyet hakkının özüne dokunan bir müdahale niteliği taşıyan kamulaştırmaya ilişkin hükümlerin mümkün olduğunca dar yorumlanması gerekmektedir. Kaldı ki 46. maddenin 3. fikrasında işletme ruhsat sahibine

97 TANRIVERMIŞ, s. 157; TOPALOĞLU, (2011), s. 328-329.

98 GÖĞER, s. 130.

99 “... 3213 sayll Maden Yasası'nın 46. maddesinin 1. fikrasında "maden arama dönemi içerisinde arama sahası özel mülkiyete konu gayrimenkul üzerinde kullanma amacina münhasır olmak üzere belli süreler için madenci, Bakanlığa müracaat ile irtifak velveya intifa hakk tesisi isteyebilir". 2. fikrasında ise "irtifak velveya intifa hakkı karşılığl, Kamulaştırma Kanunu'na uygun olarak seçilecek bilirkişiler tarafindan tespit edilir", hükümleri konulmuştur. Bu yasal düzenlemeye göre, maden işleticisinin özel mülkiyete konu olan bu yer üzerinde bedelini ödemek suretiyle irtifak hakkı kurması gerekmektedir..." Yargıtay 4. Hukuk Dairesi, T. 21.04.2003, E. 2003/2711, K. 2003/5002, Kazancı İçtihat Bilgi Bankası.

${ }^{100}$ TOPALOĞLU, (2011), s. 330. 
bir imkân daha tanınmıştır: "işletme ruhsat sahasında ve/veya mücavirinde kurulacak tesislerde kullanilacak ve ruhsat sahası dişından getirilecek olan su, doğalgaz, elektrik ve haberleşme hatları için ruhsat sahibi Genel Müdürlüge müracaat ederek irtifak velveya intifa hakk tesisi isteyebilir". Dolayısıyla kamulaştırma imkânı yalnızca işletme ruhsat alanında kalan özel mülkiyete konu taşınmazlar açısından söz konusu olmalıdır ${ }^{101}$. Yapılacak değerlendirme neticesinde işletme faaliyetleri için gerekli olduğu tespit edilen özel mülkiyetteki diğer taşınmazlar açısından ise koşullar gerçekleşmişse irtifak hakkının tesis edilmesi talep edilebilecektir.

\subsection{Satın Alma Usulünün Denenmesi}

İşletme ruhsat sahibi, Enerji ve Tabii Kaynaklar Bakanlığı'ndan ruhsat alanının kamulaştırılmasını talep etmeden önce, taşınmaz malikiyle anlaşarak satın alma yoluna başvurmak zorundadır. Taşınmaz malın mülkiyetinin zorla elde edilmesi yöntemi olan kamulaştırma usulüne son çare olarak başvurulması gerekmektedir. İşletme ruhsat sahibi, ruhsat alanında yer alan özel mülkiyete konu taşınmazı satın alma iradesini ruhsat sahibine belirli bir usul çerçevesinde iletmelidir. Zira ruhsat sahibinden, kamulaştırma talebinde bulunmadan önce, işletme faaliyetleri için gerekli taşınmaz malı satın alma iradesini malike ilettiğini belgelemesi istenmektedir ${ }^{102}$.

Maden Yönetmeliği'nin 74. maddenin 2. fikrasının f bendinde, "ruhsat sahibince kamulaştırllmast istenilen arazi sahiplerine anlaşmak üzere noter aracılı̆̆ ile yapılmış 11/2/1959 tarihli ve 7201 sayll Tebligat Kanunu hükümlerine göre gönderilen ihbarname"nin kamulaştırma talebine eklenmesi gerektiği ifade edilmektedir. Bu hüküm uyarınca ruhsat sahibinin satın alma talebini içeren ihbarnameyi noter vasıtasıyla tebliğe çıkarması ve 7201 sayılı Tebligat Kanunu ${ }^{103}$ hükümleri uyarınca tebligatın yapılması gerekmektedir. Aksi durumda satın alma yolunun tüketildiğinden bahsedilemeyecektir.

\subsection{Yetkili Makam ve Kamulaştırma Talebi}

Maden Kanunu kapsamında ruhsat sahibi lehine yapılacak kamulaştırmalarda yetkili makam Enerji ve Tabii Kaynaklar Bakanlığı' dır ${ }^{104}(\mathrm{MK}$ m. 46/5). Ancak Bakanlığın resen harekete geçerek

\footnotetext{
101 ÇEVIKKÇELİK, s. 147-148.

102 TOPALOĞLU, (2011), s. 330.

103 19.02.1959 tarih ve 10139 sayıl1 Resmi Gazete.

104 FINDIKLIGIL, s. 101; GÜLAN, (2008), s. 202.
} 
kamulaştırma işlemlerine başlama hususunda yetkisi bulunmamaktadır. Malike taşınmazı satın alma iradesini noter aracılığıyla ihbar ettiren fakat anlaşma sağlayamayan ruhsat sahibi, ruhsat alanında işletme faaliyetlerinde bulunabilmek için Maden ve Petrol İşleri Genel Müdürlüğüne başvurarak ruhsat alanının kamulaştırılmasını talep etmelidir ${ }^{105}$. Zira ruhsat sahipleri ile mal sahiplerini karşı karşıya bırakmak, sürecin uzamasına ve madenlerin çıkarılıp ekonomiye kazandırılmasının engellenmesine yol açacaktır ${ }^{106}$.

Ruhsat sahibi tarafından yapılacak kamulaştırma talebine Maden Yönetmeliği'nin 74. maddenin 2. fikrasında yer alan belgelerin eklenmesi gerekmektedir. Maddede sayılan belgeler şunlardır:

“a) Kamulaştırma talebi ile ilgili dilekçe,

b) Tüzel kişilerde kamulaştırma ile ilgili karar,

c) Kamulaştırılması düşünülen alanın imar ve kullanım durumu, süresi, rezerv durumu, kamulaştırma sonrası ruhsat alanındaki faaliyetlerin ekonomiye katkısı ile ilgili karşılaştırmalı bilgileri içeren proje,

c) Kamulaştırılması talep edilen alan ve bu alan üzerindeki taşınmazların miktar ve nitelikleri, bu alanın 6 derecelik dilime esas koordinatlarl, sahiplerinin isim ve adresleri, arazilerin tapu ve çap suretlerini gösterir tapu sicilinden onayll listesi,

d) Taşınmaz üzerinde kamulaştırma sonrası yapılması düşünülen üretim tesisleri ve işletmenin durumunu gösterir vaziyet planı,

e) Üretimden sonra arazinin restorasyonu hakkındaki bilgileri ve haritasl,

f) Ruhsat sahibince kamulaştırılması istenilen arazi sahiplerine anlaşmak üzere noter aracıliğ ile yapılmış 11/2/1959 tarihli ve 7201 sayll Tebligat Kanunu hükümlerine göre gönderilen ihbarname,

g) Kamulaştırılması talep edilen arazinin çevresindeki yerleşim alanları ve arazi konumlarl."

Ruhsat sahibi tarafindan yapılacak başvuru yerinde görülürse, talep kabul edilerek kamulaştırma işlemlerine başlanacaktır. Özel hukuk kişisi

\footnotetext{
105 TOPALOĞLU, (2011), s. 330-331.

106 GÖĞER, s. 136-137.
}

352 Ankara Hacı Bayram Veli Üniversitesi Hukuk Fakültesi Dergisi C. XXIV, Y. 2020, Sa. 1 
lehine yapılacak kamulaştırmalarda Enerji ve Tabii Kaynaklar Bakanlığ tarafından kamu yararı kararı alınacaktır. Kamulaştırma Kanunu'nun 6. maddesi uyarınca, Bakanlıklar tarafindan verilen kamu yararı kararlarının onaylanmasına gerek bulunmamaktadır. Dolayısıyla Enerji ve Tabii Kaynaklar Bakanlığının ruhsat alanının özel hukuk kişisi lehine kamulaştırılmasına ilişkin verdiği kamu yararı kararı ayrıca onaylanmaksızın ${ }^{107}$ söz konusu karar ilgili valiliğe gönderilecektir. İlgili valilik, kamulaştırma işlemlerini 2942 sayılı Kamulaştırma Kanunu hükümleri doğrultusunda sonuçlandıracaktır (MY m. 75/8).

\subsection{Kamulaştırma Bedeli}

Kamulaştırma işlemlerinde ilk adım, kamulaştırma için yeterli ödeneğin temin edilmesidir. (KK m. 3/4). Yeterli ödenek temin edilmeksizin kamulaştırma işlemlerine başlanması mümkün değildir. Özel hukuk kişileri lehine yapılacak kamulaştırmalarda ise kamulaştırma bedeli kısmen veya tamamen özel kişiler tarafindan karşılanmaktadır ${ }^{108}$. Bu doğrultuda Maden Kanunu kapsamında özel hukuk kişisi lehine yapılan kamulaştırmalarda, kamulaştırma sürecine ilişkin masrafların ve kamulaştırma bedelinin ruhsat sahibi tarafından karşılanması gerekmektedir (MK m. 46/6).

Ruhsat alanının kamulaştırılması aşamasında ruhsat sahibinden kamulaştırma masrafları ve bedelinin istenmesi, özel hukuk kişisi lehine yapılan kamulaştırmalara ilişkin genel prensiplere uygundur. Maden Kanunu’nun 46. maddesinin 10. fikrasında istisnai bir düzenleyeme yer verilmiştir. Bu hüküm uyarınca "hazinenin özel mülkiyetinde veya Devletin hüküm ve tasarrufundaki yerlerde yapılan madencilik faaliyetleri için bu Kanunun yürürlük tarihinden sonra kira, ecrimisil alınmaz".

Kanun'un 46. maddesinin 6. fikrası ile 10. fikrası arasındaki bu farklılık oldukça önemli bir sorunu beraberinde getirmektedir. Zira özel hukuk kişisinin mülkiyetinde olan bir taşınmaz üzerinde işletme faaliyetlerinde bulunmak isteyen ruhsat sahipleri kamulaştırma bedeli ve diğer masrafları karşılamak zorundayken, devletin hüküm ve tasarrufu altındaki taşınmazlar ile hazinenin özel mülkiyetindeki taşınmazlar üzerinde işletme faaliyetlerinde bulunmak isteyen ruhsat sahipleri kira, ecrimisil gibi herhangi bir bedel ödemek

\footnotetext{
107 BÜYÜKTAVŞAN, s. 42.

108 AKYILMAZ/ SEZGINER/ KAYA, s. 597-598; SOLMAZ, s. 24.
} 
zorunda değildir ${ }^{109}$. Bu durumda ruhsat sahipleri arasında makul olmayan mali yükümlülük farkı meydana gelmektedir ${ }^{110}$. Ancak Anayasa Mahkemesi söz konusu düzenlemenin "madencilik faaliyetlerini geliştirmek, özendirmek, teşvik etmek, alacă̆ın tahsilini kolaylaştırmak gibi kamu yararı amacıyla" getirildiğini ve bu hususta düzenleme yapma konusunda kanun koyucunun takdir yetkisinin olduğunu ifade ederek söz konusu hükmü hukuka aykırı görmemiştir ${ }^{111}$.

Ruhsat sahipleri arasındaki eşitsizliğin dengelenmesi amacıyla Maden Kanunu'nun 14. maddesine 5995 sayılı Maden Kanununda ve Bazı Kanunlarda Değişiklik Yapılmasına Dair Kanun"12 ile "hazinenin özel mülkiyetinde veya Devletin hüküm ve tasarrufu altında bulunan yerlerde yapılacak madencilik faaliyetlerinden Devlet hakkı \% 30 fazlasıyla alınır” hükmü eklenmişti. Ancak 6592 sayılı Maden Kanunu ile Bazı Kanunlarda Değişiklik Yapılmasına Dair Kanun ${ }^{113}$ ile yapılan değişiklikle bu hüküm kaldırılmıştır. Kanun'un gerekçesinde ilgili hükmün kaldırılmasına dair bir açılama yer almasa da, genel olarak söz konusu maddede yapılan değişikliklerle devlet haklarının

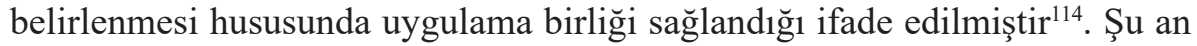
için Maden Kanunu'nda ruhsat sahipleri arasında meydana gelen eşitsizliği dengeleyici bir mekanizma bulunmamaktadır.

\subsection{Kamulaştırılan Tașınmazın Kullanılması}

Maden Kanunu'nun 46. maddesi uyarınca kamulaştırılan taşınmaz Hazine adına tescil edilmekte ve işletme ruhsat sahibine tahsis edilmektedir.

${ }^{109}$ ÇEVIKÇELIK, s. 149; “...Tüm bu düzenlemelerin birlikte değerlendirilmesi sonucunda, davacı şirketin uyuşmazlık konusu hazine tașınmazını, Maden Kanunu hükümlerine göre Enerji ve Tabii Kaynaklar Bakanlığı Maden Dairesi Bașkanlığından almış olduğu işletme ruhsatına dayanarak kullandığ , maden işletme ruhsatında belirtilen saha içindeki çalıșmalarından dolayı fuzuli șagil olarak nitelendirmesinin mümkün olmadiğı, dolayısıyla ecrimisil istenilmesinde mevzuata uyarlık bulunmadiğı anlaşıldiğından, İstanbul 2. İdare Mahkemesinin, davacıyı fuzuli şagil olarak nitelendirmesinde yasal isabet görülmemiştir..." Danıştay İdari Dava Daireleri Genel Kurulu, 16.02.1996, E. 1994/401, K. 1996/92, Kazanc1 İçtihat Bilgi Bankası; Aynı yönde bkz. Yargıtay 6. Hukuk Dairesi, T. 29.03.2011, E. 2011/1651, K. 2011/3839, Kazanc1 İçtihat Bilgi Bankas1.

110 GÜLAN, (2008), s. 203.

${ }^{111}$ Anayasa Mahkemesi, T. 15.01.2009, E. 2004/70, K. 2009/7, 11.06 .2009 tarih ve 27255 say1lı Resmi Gazete.

112 24.06.2010 tarih ve 27621 say11 Resmi Gazete.

113 18.02.2015 tarih ve 29271 say1l Resmi Gazete.

114 “...Devlet haklarının belirlenmesi ve Genel Müdürlükçe duyurulması sağlanarak emsal fiyatlarda uygulama birliği să̆lanmıştır...” 
Kamulaştırılan taşınmazın mülkiyeti Hazineye aittir. Madencilik faaliyetleri sona erdiğinde taşınmaz mülkiyeti Hazinede kalmaya devam edecektir ${ }^{115}$. Tahsis işlemi, kamulaştırma işlemi ile Hazine adına tescil edilen taşınmazın, mülkiyeti Hazinede kalmak kaydıyla, madencilik faaliyetlerinde kullanılmak amacıyla ruhsat sahibine bırakılmasına yönelik bir idari işlemdir ${ }^{116}$.

Kamulaştırılan taşınmaz, "ruhsat hukuku devam ettiği sürece" ruhsat sahibine tahsis edilecektir (MK m.46/7). Tahsis süresi, işletme ruhsat süresi ile sınırlıdır. İşletme ruhsatının herhangi bir şekilde sona ermesi halinde tahsis işlemi de sona erecektir. Keza işletme ruhsatının devri halinde tahsis işleminin devralan adına değişmesi gerekmektedir ${ }^{117}$.

Kamulaştırılan taşınmazın kamulaştırma amacına uygun olarak kullanılması gerekmektedir"18. "Ruhsat sahibinin kamulaştırılan alanı kamulaştırma amacı dışında kullanması ve/veya ruhsat alanını madencilik faaliyetleri dışında kullanması ve/veya kullandırması " haksız yere hak iktisabı sayılır ve bu hususta verilecek beyanlar gerçek dışı ve yanıltıcı beyan olarak kabul edilir (MK m. 10/7). Bununla birlikte ruhsat sahibi lehine kamulaştırılan taşınmazda, kamulaştırma amacı dışında yürütülen faaliyetler durdurulacaktır (MY m. 75/4).

\subsection{Mal Sahibinin Geri Alma Hakkı}

Mal sahibinin taşınmazı geri alma hakkı, kural olarak, özel hukuk kişileri lehine yapılacak kamulaştırmalar için de geçerlidir ${ }^{119}$. Eski malik, kendisine yapılan bildirimden itibaren altı ay içinde geri alma hakkını kullanabilir. Ancak altı ay içerisinde geri alma hakkının kullanılmaması üzerine, taşınmaz Hazineye kalacaktır (MK m.46/8).

\section{SONUÇ}

Maden arama veya işletme ruhsatı almak ruhsat sahibine, özel hukuk kişisinin mülkiyetinde olan ruhsat alanında madencilik faaliyetlerinde

\footnotetext{
115 GÜLAN, (2008), s. 202-203.

${ }^{116}$ KIRBAŞ, s. 135; ONAR, Cilt II, s. 1345; Tahsis, genel olarak, idari bir işlemle gerçekleşmektedir. Bununla birlikte hukukumuzda kanun, yönetmelik, imar planları ve idari sözleşmeler ile tahsis müessesesinin ortaya çıktığı da görülmektedir. GÜLAN, (1999), s. 98-99; ONAR, Cilt II, s. 1345-1349.

${ }^{117}$ Zira kamulaştırılan taşınmazın ruhsat sahibine tahsisi ile işletme ruhsatına bağlı eşyaya bağlı borç statüsü yaratılmaktadır. TOPALOĞLU, (2011), s. 334; GÖĞER, s. 173.

118 FINDIKLIGILL, s. 104; ÖZYÖRÜK, s. 97.

${ }^{119}$ FINDIKLIGİL, s. 104.
} 
bulunma hususunda yetki vermemektedir. Ruhsat sahibinin özel mülkiyete tabi ruhsat alanındaki madencilik faaliyetlerinin hukuka uygun sayılabilmesi için Maden Kanunu'nun 46. maddesi uyarınca lehine irtifak ve/veya intifa hakk1 tesis edilmesi veya söz konusu taşınmazın kamulaştırılması gerekmektedir. Ruhsat sahibi lehine taşınmaz üzerinde irtifak veya intifa hakkı tesis edilmesi malikin mülkiyet hakkını sinırlarken, ruhsat alanının ruhsat sahibi lehine kamulaştırılması malikin mülkiyet hakkını sona erdirmektedir. Dolayısıyla kamulaştırma yoluna, Anayasa ve diğer mevzuat hükümleri doğrultusunda son çare olarak başvurulmalıdır.

Maden hukukunda kamulaştırma usulüne yalnızca işletme ruhsatı aşamasında ve işletme faaliyetleri için gerek duyulduğu takdirde başvurulabilmektedir. Ancak kamulaştırma usulüne başvurulmadan önce, ruhsat sahibi lehine irtifak ve/veya intifa hakkının tesis edilmesinin işletme faaliyetleri açısından yeterli olup olmayacağı değerlendirilmelidir.

Mevzuatımızda idarenin işleyişini ve karar alma sürecini düzenleyen genel idari usul kanunu şu an için bulunmamaktadır. Ancak çeşitli kanunlarda idari usule ilişkin düzenlemelere rastlanabilmektedir. Kamulaştırma işleminin idarece tesis edilmesine ilişkin aşamalar ise Kamulaştırma Kanunu'nda ayrıntılı olarak düzenlenmiştir. Maden hukukunda işletme ruhsat alanlarının kamulaştırılmasında Kamulaştırma Kanunu'nun uygulanacağ edilmekle birlikte, Kanun'un 46. maddesinde birtakım ayrıksı düzenlemelere yer verilmiştir.

Gerek kamulaştırma talep edilebilecek madenlerin sınırlandırılması, gerek kamulaştırma masraf ve bedelinin ruhsat sahibi tarafından karşılanması, gerekse mal sahibinin taşınmazı geri alma hakkı noktalarında Maden Kanunu ile Kamulaştırma Kanunu arasında birtakım farklılıklar olsa da değişmeyen en önemli husus kamu yararı kararının alınmasıdır. Zira her ne kadar Maden Kanunu'nun 46. maddesinde öngörülen kamulaştırma usulü, özel hukuk kişileri lehine yapılacak kamulaştırmanın bir örneğini teşkil etse de yetkili idare tarafından kamu yararı kararı alınması bir gerekliliktir. Zira kamu yararı kararı, idarenin cebren özel mülkiyete müdahale etmesine izin vererek söz konusu müdahaleyi hukuka uygun hale getirmektedir. 


\section{KAYNAKÇA}

AKYILMAZ, Bahtiyar/ SEZGINER, Murat/ KAYA, Cemil: Türk İdare Hukuku, Yenilenmiş 9. Baskı, Savaş Yayınevi, Ankara, 2018.

ARTUKMAÇ, Sadık: Kamulaştırma Hukuku, Ayyıldız Matbaası, Ankara, 1977.

ATAY, Ender Ethem: İdare Hukuku, 6. Bas1, Turhan Kitabevi, Ankara, 2018.

AZRAK, Ali Ülkü: “Türkiye'de Madenlerin Hukuki Rejimi Üzerine Düşünceler”, İdare Hukuku ve İlimleri Dergisi, Cilt 1, Say1 2, 1980, s. 3-9.

BÜYÜKTAVŞAN, Muhammed Taha: Kamulaştırmada Malikin Hakları ve Yükümlülükleri, Yayımlanmamış Yüksek Lisans Tezi, Gazi Üniversitesi Sosyal Bilimler Enstitüsü, Ankara, 2012.

ÇAĞATAY, S. Seda/ ALİEFENDİOĞLU, Yeşim: "Metal Madencilik Faaliyetleri Arazi Edinim Süreci: Erzincan İli İliç İlçesi, Çöpler Altın Madeni”, Social Sciences Research Journal, Volume 8, Issue 1, March 2019, s. 223-241.

ÇAĞLAYAN, Ramazan: "Kamulaştırma İşleminin İptali ve Mülkiyetin Âkibeti”, İstanbul Üniversitesi Hukuk Fakültesi Mecmuası, Cilt 69, Sayı 1-2, Aralık 2011, s. 453-466.

ÇAKMAK, Naci Münci: İdare Hukukunda Kuramsal Olarak Kamu Yararı, Seçkin Yayıncılık, Ankara, 2013.

ÇANGA, Halit Erol: 5177 Sayılı Açıklamalı Maden Kanunu ve Yönetmelikleri, Yurt Madenciliğini Geliştirme Vakfı Yayınları, İstanbul, 2005.

ÇEVIKKÇELIKK, Muradiye: Türk İdare Hukukunda Maden İşletme ve Rödovans Sözleşmeleri, Seçkin Yayıncılık, Ankara, 2017.

ÇİTİL, Bünyamin: Tüm Yönleriyle Maden Hukuku (Cumhurbaşkanlığı Sistemi KHK ve Kararnameleri Işı̆̆ında), Seçkin Yayıncılık, Ankara, 2018.

DURAN, Lütfi: Türkiye İdaresinin Sorumluluğu Sorumluluğun Temeli ve Sebepleri Sorumluluğa Yol Açan Olgular, Türkiye ve Orta Doğu Amme İdaresi Enstitüsü Yayınları No: 138, Sevinç Matbaası, Ankara, 1974. 
DÜREN, Akın: Devletin Mülkiyete El Atmasından Doğan Tazmin Yükümlülüğ̈̈̈, Sevinç Matbaas1, Ankara, 1977.

ERDOĞAN, Kemal: Rödövans Sözleşmesi, Seçkin Yayıncılık, Ankara, 2017.

Eti Maden İşletmeleri Genel Müdürlüğü: Maden Terimleri Sözlüğü http://www. etimaden.gov.tr/maden-terimleri-sozlugu/m-harfi-ile-baslayanlar\#, Erişim Tarihi: 25.08.2019.

FINDIKLIGİL, Yavuz: Maden Hukuku, İstanbul Teknik Üniversite Matbaası, İstanbul, 1966.

GÖĞGR, Erdoğan: Maden Hukuku, Sevinç Matbaası, Ankara, 1979.

GÖVEN, Yusuf: "Kamulaştırma İşlemlerinde "Kamu Yararı"”, Dumlupınar Üniversitesi Sosyal Bilimler Dergisi, Say1 1, Ocak 1999, s. 247-262.

GÖZLER, Kemal: İdare Hukuku Dersleri, Güncellenmiş 21. Bask1, Ekin Basın Yayın Dağıtım, Bursa, 2019.

GÜLAN, Aydın: Kamu Hizmeti ve Görülüş Usulleri, Yayımlanmamış Yüksek Lisans Tezi, İstanbul Üniversitesi Sosyal Bilimler Enstitüsü, İstanbul, 1987.

GÜLAN, Aydın: Kamu Mallarından Yararlanma Usullerinin Tabi Olduğu Hukuki Rejim, Alfa Basım Yayım Dağıtım, İstanbul, 1999.

GÜLAN, Aydın: Maden İdare Hukukumuzun Ana İlkeleri ve Temel Müesseseleri Mevzuat ve Yargı kararları Işığında Eleştirel Bir Yaklaşım Denemesi, Lamure, İstanbul, 2008.

GÜNAY, Ömer: Maden Hukuku Kavramlar- İlkeler- Tanımlar (Güncel Danıştay Kararlarıyla), Güncellenmiş İkinci Baskı, Seçkin Yayıncılık, Ankara, Nisan 2017.

GÜNDAY, Metin: İdare Hukuku, 11. Bask1, İmaj Yayınevi, Ankara, 2017.

INNCEOĞLU, Sibel: “Anayasa ve Kanunlarda Kamulaştırmanın Düzenlenişi”, Argumentum, Cilt 1, Say1 5, Aralik 1990, s. 70-76.

KALABALIK, Halil: “Genel İdari Usül Kanunu Bulunmayan Ülkemizde Kanunla Usüle Bağlanmış Bir İşlem: Kamulaştırma Üzerine Bir İnceleme", Yönetim ve Ekonomi: Celal Bayar Üniversitesi İktisadi ve İdari Bilimler Fakültesi Dergisi, Cilt 4, Say1 1, 1998, s. 299-346.

KARAHANOĞULLARI, Onur: Kamu Hizmeti (Kavram ve Hukuksal Rejim), 3. Bas1, Turhan Kitabevi, Ankara, 2015.

KAYA, Cemil: "Kiracıların Sübjektif Dava Ehliyeti Konusunda Danıştay 
Kararlarının Değerlendirilmesi”, İstanbul Üniversitesi Hukuk Fakültesi Mecmuası, Cilt 69, Sayı 1-2, 2011, s. 335-347.

KAYA, Cemil: Kararlarından Hareketle Kamu Yararı Kavramına Danıştay’ın Bakışı, On İki Levha Yayıncılık, İstanbul, 2011.

KIRATLI, Metin: "İdarenin Bayındırlık Hizmetleri”, Ankara Üniversitesi Siyasal Bilgiler Fakültesi Dergisi, Cilt XXVII, Say1 4, Aralık 1972, s.53-81.

KIRBAŞ, Sadık: Devlet Malları, İkinci Baskı, Adım Yayıncılık, Ankara, 1988.

KIZIL (Erkelli), Neşe: “Kamulaştırma Fenomeni”, İdare Hukuku ve İlimleri Dergisi, Prof. Dr. Lütfi Duran'a Armağan Özel Sayıs1, Cilt 9, Say1 1-3, 1988, s. 209-216.

KUTLU GÜRSEL, Meltem: “Teknoloji Geliştirme Bölgesinde Kamulaştırma ve Ruhsat(İzin) Verme Yetkisi”, Dokuz Eylül Üniversitesi Hukuk Fakültesi Dergisi, Cilt 9, Özel Say1, 2017, s. 999-1018.

KUTLU, Meltem: İdari Bir İşlem Olarak Kamulaştırma ve İptal Davası, Dokuz Eylül Üniversitesi Hukuk Fakültesi Döner Sermaye İşletmesi Yayınlar1, No: 24, Ankara, 1992.

ONAR, Sıddık Sami: İdare Hukukunun Umumî Esasları, Cilt II, 3. Bası, İsmail Akgün Matbaası, İstanbul, 1966.

ONAR, Sıddık Sami: İdare Hukukunun Umumî Esasları, Cilt III, 3. Bası, İsmail Akgün Matbaası, İstanbul, 1966.

ÖZDAMAR, Demet: "Maden Hakkı ve Maden İrtifakı", Dokuz Eylül Üniversitesi Yayını: Prof. Dr. Mahmut Tevfik BİRSEL’e Armağan, 2001, s. 319-335.

ÖZTOPRAK, Sezin: (6592 Sayılı Kanun İle Yapılan Değişikliklerle) Kömür Ocaklarının Özel Hukuk Kişileri Tarafından İşletilmesi, Yetkin Yayınlar1, Ankara, 2015.

ÖZYÖRÜK, Mukbil: Kamulaştırma Hukuku, Günay Matbaacılık, Ankara, 1948.

SOLMAZ, Eren: Kamulaştırma Hukukunda Malikin Geri Alma Hakkı, On İki Levha Yayınc1lık, İstanbul, 2016.

SÖYLER, İlhami: "Kamu Malları Teorisi Açısından Devletin Hüküm ve Tasarrufundaki Yerler”, Sayıştay Dergisi, Sayı 83, 2011, s. 57-68. 
ŞAHİN, Cenk: “Kamulaştırma”, İl Han Özay, Günışığında Yönetim İçinde, Filiz Kitabevi, İstanbul, 2017.

ŞİMŞEK, Suat: "Kamu Mallarının Özel Mülkiyete Konu Olmaması İlkesinin Mülkiyet Hukukuna Yansımaları", Sayıştay Dergisi, Sayı 92, 2014, s. 93-115.

TANRIVERMIŞ, Harun: "Madencilik Faaliyetlerinde Arazi Edinimi, kamulaştırma ve Değerleme Üzerine", Madencilik Türkiye Dergisi, Say1 75, 2018, s. 156-166.

TELLİ, Serap: İdare Hukuku ve Uluslararası Hukuk Açısından Madenler,

S Yayınları, Ankara, 1989.

TEZCAN, Murat: "Kamulaştırma Yoluyla Mülkiyet Transferi", Türkiye Barolar Birliği Dergisi, S. 108, 2013, s. 377-382.

TOPALOĞLU, Mustafa: Maden Hukuku, Karahan Kitabevi, Adana, 2011.

TOPALOĞLU, Mustafa: "Yeni Yasal Düzenleme ve Maden İrtifakları", Türkiye Madenciler Derneği Sektörden Haberler Bülteni, Sayı 58, 2015, s. 76-80.

TÜRK, Hikmet Sami: "Devletçe İşletilecek Madenler Hakkında Kanun Üzerinde Açıklamalar", Ankara Üniversitesi Hukuk Fakültesi Dergisi, Cilt 36, Say1 1-4, Ocak 1979, s.83-119.

Türkiye Büyük Millet Meclisi (TBMM): Madencilik Sektöründeki Sorunların Araştırılarak Alınması Gereken Önlemlerin Belirlenmesi Amacıyla Kurulan Meclis Araştırması Komisyonu Raporu, https://www.tbmm. gov.tr/sirasayi/donem23/yil01/ss544.pdf (Erişim tarihi: 10.09.2019).

ULUSAN, İlhan: "Alman Kamu Hukukunda Fedakârlığın Denkleştirilmesi İlkesi”, İstanbul Üniversitesi Hukuk Fakültesi Mecmuası, C. 43, S. 1-4, 1977, s. 101-130.

YILDIRIM, Turan: "Kamulaştırmadan Vazgeçme", Kazancı Hakemli Hukuk Dergisi, Sayı 101, 2013, s. 7-23.

YILDIZ, Taşkın Deniz: "Türk Maden Mevzuatı Evriminde Madenlerin Mülkiyeti ve Rejimi”, 22rd International Mining Congress \& Exhibition of Turkey, 16-19 Nisan 2019, Antalya, s. 1959-1980.

ZEVKLILER, Aydın: "Kamulaştırma, Satımın Özel Bir Çeşidi Midir?", Ankara Üniversitesi Hukuk Fakültesi Yayınları: Prof. Dr. Osman Fazıl Berki'ye Armağan, No: 411, Ankara, 1977, s. 935-958. 